\title{
Fen Bilimleri Eğitiminde Karşılaşılan Kavram Yanılgılarına İlişkin Lisansüstü Tezlerin Tematik İçerik Analizi
}

\section{Erkan YANARATEŞ ${ }^{*}$}

Öz: 2000'li yılların başından itibaren Türkiye'de fen bilimleri eğitimi kapsamında kavram yanılgıları ile ilgili tez, makale veya kitap olarak birçok araştırma yapılmış ve halen de yapılmaya devam etmektedir. Araştırma kapsamındaki yüksek lisans ve doktora tezleri incelendiğinde genel olarak fen bilimleri derslerinde öğrencilerin fizik, kimya ve biyoloji ile ilgili kavramlara değişik anlamlar yükledikleri belirtilmektedir. Ayrıca araştırmacıların kavram yanılgılarını azaltmaya yönelik çözüm önerilerinde bulunduğu ve bu konuda çözüm yollarına ihtiyaç olduğu vurgulanmaktadır. Bu bağlamda araştırmada, 2001-2020 yılları arasında Türkiye’de yapılan, fen bilimleri eğitiminde karşılaşılan kavram yanılgılarına ilişkin 136 tane lisansüstü tezin tematik içerik analizi yapılmıştır. Araştırmadaki tezlerin türleri, yayın yılları, yazım dilleri, yayımlandıkları enstitüler, amaçları, konuları, araştırma yöntemleri, veri analiz yöntemleri, çalışma grupları, örneklem sayıları, veri toplama araçları, ulaştıkları sonuçlar ve sundukları öneriler tespit edilmiştir. Toplanan veriler temalar halinde sınıflandırılarak tezlere ilişkin doküman analizi yapılmıştır. Araştırmadaki temaların zenginliği bakımından ve kavram yanılgıları ile ilgili ulaşılan verilerin tekrar araştırmaya gerek kalmaması bakımından alan yazına katkı sağlaması düşünülmektedir. Ayrıca elde edilen bulguların bundan sonra yapılacak olan ilgili çalışmalara 1şık tutması beklenmektedir.

Anahtar Kelimeler: Fen bilimleri eğitimi, kavram, kavram yanılgıları, tematik içerik analizi

\footnotetext{
* Dr. Öğretim Üyesi, Kastamonu Üniversitesi, Eğitim Fakültesi, Matematik ve Fen Bilimleri Eğitimi Bölümü, eyanarates@kastamonu.edu.tr http://orcid.org/0000-0003-1378-5284
} 


\section{Thematic Content Analysis of Graduate Theses on Misconceptions Encountered in}

\section{Science Education}

Abstract: Since the early 2000s, many research types have been done and continue to be done as theses, articles, or books on misconceptions within Turkey's science education scope. When the theses in the research field are examined, students usually make different meanings in concepts related to physics, chemistry, and biology in science courses. Also, it is emphasized that researchers have proposed solutions to reduce misconceptions, and solutions are needed in this regard. In this context, the thematic content analysis of 136 graduate theses on the misconceptions encountered in science education was carried out in Turkey between 2001 and 2020. The thesis types in the research, the years of publication, the writing languages, the institutes in which they were published, purposes, topics, research methods, data analysis methods, working groups, sampling numbers, data collection tools, the results they reached, and the suggestions they presented were determined. The collected data were classified into themes, and document analysis of the theses was carried out. The richness of the research themes, and the data obtained about the misconceptions do not need to be re-investigated. The findings are also expected to shed light on future studies.

Key Words: Science education, concept, misconceptions, thematic content analysis

\section{Giriş}

Akademik çalışmalarda ve günlük hayatta sürekli karşılaşılan "fen" ve "eğitim" kavramlarında olduğu gibi "fen bilimleri" ve "eğitim bilimleri" kavramlarının da birbirlerine göre oldukça farklılık gösterdikleri bilinmektedir. Bu iki kavramın sentezlenmesiyle meydana gelen "Fen Bilimleri Eğitimi” bilim dalından, kendini oluşturan bilim dallarının özelliklerini taşıması gerekmektedir. Beklentiler bu doğrultudadır, ancak karşılaşılan kavram yanılgıları bakımından fen bilimleri eğitimi diğerlerine nazaran farklılık gösterebilir. Çünkü fen bilimleri eğitimi; fiziksel, kimyasal, biyolojik ve hatta çevre ile ilgili birçok metafor (Yanarateş ve Y1lmaz, 2020) içermesi bakımından çok geniş bir kavram yelpazesine sahiptir. Bu sebeple yaş ve öğrenim seviyesine bakılmaksızın, birçok birey fen bilimlerine ait kavramları anlamlı bir şekilde öğrenme sırasında birtakım zorluklarla karşılaşmaktadırlar (Yavuz, 2017).

Araştırılan konuyla ilgili olarak hem nitel (kalitatif) hem de nicel (kantitatif) araştırmaların incelendiği çalışmalarda betimsel içerik analizi yöntemi tercih edilmelidir (Polat ve Ay, 2016). Ancak bu yöntemin kullanıldığı araştırmalarda genel durumu göstermek 
amacıyla herhangi bir temanın sadece frekans ve yüzde verileriyle genel örüntüsü belirtilerek detaylı bir yorum yapılmamaktadır (Dinçer, 2018). Dolayısıyla nicel ve nitel çalışmalar birlikte ele alınacaksa ve genel bir durum ortaya koyulacaksa betimsel içerik analizi kullanılmalıdır. Çünkü bu yöntemde ayrıntılı şekilde bir konuya değinilmediğinden, net bir bulgu elde edilemeyebilir (Çepni, 2018). Bu bağlamda bu çalışma, Türkiye'de fen bilimleri eğitiminde karşılaşılan kavram yanılgılarına ilişkin yapılan yüksek lisans ve doktora tezlerinin genel eğilimlerini tespit etmek amacıyla gerçekleştirilen bir tematik içerik analizidir. Benzer temalarda söz konusu tezlerle ilgili daha önceden yapılmış araştırmalara da rastlanmaktadır. Kavram yanılgılarıyla ilgili yapılan akademik çalışmaların giderek artması, bu konunun önemini ve konuyla ilgili bazı çözüm önerilerine ihtiyaç olduğunu göstermektedir. Bu araştırmadaki tezlerin çalışılma oranı da son yıllarda daha yüksek çıkmaktadır.

Yükseköğretim Kurumu [YÖK]-Ulusal Tez Merkezi resmî Internet sitesinden elde edilen verilere göre son 20 yılda (2001-2020) fen bilimleri eğitiminde karş1laşılan kavram yanılgılarına ilişkin 20 tane doktora tezi ve 116 tane yüksek lisans tezinden oluşan toplam 136 tane izinli lisansüstü tez bulunmaktadır (YÖK, 2021).

Araştırmadaki bulguların bir kısmı alan yazındaki içerik analizi çalışmalarıyla tematik olarak birtakım benzerlikler göstermektedir (Sinan, 2010; Türkdoğan, Güler, Bülbül, Danişman, 2015; Adıgüzel, Şimşir, Çubukluöz, Gökkurt Özdemir, 2018; Tayan, Gedik, Morkoyunlu, Sözbilir, Konyalığlu, 2019). Ancak bu çalışmadaki bulgular hem konu olarak hem de tematik olarak söz konusu araştırmalara göre oldukça farkl1lık göstermektedir. Başka bir deyişle araştırma kapsamındaki yüksek lisans ve doktora tezlerinin, yayın yılları, yazım dilleri, yayımlandığı enstitüler, amaçları, araştırma konuları, araştırma yöntemleri,” veri analiz yöntemleri, çalışma grupları, örneklem sayıları, veri toplama araçları, ulaşılan sonuçlar ve sunulan öneriler gibi temaların hepsi bir arada bulunan bir çalışmaya rastlanmamıştır.

Bilginin doğasını düşünme, mevcut bilgileri idrak etme ve bu bilgilerden yeni bilgiler üretebilme sürecine fen bilimi denir. Fen bilimleri öğrenimi gören öğrencilerde, temel beceriler sayılabilecek olan sorumluluk alma duyguları, araştırma yöntemlerini kullanabilme ve öğrendikleri bilgilerin kalıcı olması gibi bilimsel beceriler gelişir. Daha sonra öğrenciler kazandıkları bu becerileri hayatlarının farklı basamaklarında kullanarak yaşantılarını kolaylaştırırlar (YÖK/Dünya Bankası, 1997).

Gündelik hayatta öğrenciler fen bilimleri eğitimi kapsamında çeşitli deneyimler kazanmaktadırlar. Bu deneyimler bazen onların doğru bilgiye ulaşabilmesini sağlarken bazen 
de yanlış bilgi edinmelerine sebep olabilmektedir. İşte bu tecrübeler öğrencilerin bilgi dağarcığını meydana getirmektedir. Öğrenme olgusu ise önceden var olan bilgilerle sonradan öğrenilen bilgiler arasında ilişki kurularak söz konusu bilgilerin anlam kazanması esasına dayanmaktadır. Öğrencinin bilgi dağarcığındaki yanlış kavramların belirlenmesi çok önemlidir. Çünkü gündelik hayatta öğrenilen yanlış kavramlar öğrencilerin öğrenmelerine engel olabilmektedir (Yağbasan ve Gülçiçek, 2003).

Anlamlı öğrenme ancak öğrencinin önceden öğrendiği kavramlarla yeni öğrendiği kavramlar arasında ilişki kurmaya başladığı zaman geçekleşir. Bu da öğrenciye öğretilen her kavramın sistematik bir şekilde yapılandırılmasıyla mümkündür. Ayrıca fizik, kimya ve biyoloji gibi alanları da bünyesinde barındıran fen bilimleri eğitiminde çok fazla soyut kavram bulunduğundan bu alanlarla ilgili derslerin öğrencilere yeterince verilmesinde ve onların derslerde son derece aktif tutulasında kavramların önemli bir yeri vardır (Bacanak, Küçük ve Çepni, 2004).

Türkiye'deki eğitim politikalarında meydana gelen değişim ve gelişmeler, aynı anda öğretim programlarının değişime gitmesine de yansımaktadır. Benzer şekilde fen bilimleri öğretim programında da değişiklik yapılmaya gidilmiş ve programın amacının "tüm öğrencileri fen okuryazarı bireyler olarak yetiştirmek" olduğu ifade edilmiştir (Millî Eğitim Bakanlığ1 [MEB], 2018).

Fen bilimleri eğitiminde temel prensip, daha önceden bilinen bir bilgiyi doğrudan öğrencilere vermek yerine söz konusu bilgiye ulaşmada onlara kılavuzluk etmektir. $\mathrm{Bu}$ prensibe uygun bir şekilde yapılan fen bilimleri eğitimi, öğrencilere yaratıcı düşünme yeteneği kazandıracağı için bu sayede öğrenciler herhangi bir problemle karşılaştıklarında durumu sorgulayarak uygun bir çözüm yolu bulacaklardır (Kaptan, 1999). Bu niteliklere sahip olan öğrencilere fen bilimleri eğitimi verilirken bilimsel olguları ezberletmekten ziyade bir tür fikir üretme tekniği şeklinde algılamaları sağlanmalıdır. Ayrıca bu teknikler öğrencilerin çevrede olup biten olayları anlamalarını sağlayacak özellikte olmalıdır. Fen bilimleri eğitiminin etkin bir şekilde verilebilmesi ancak kavramlar sevisinde ele almakla mümkündür (Koray, Özdemir ve Tatar, 2005).

\section{Kavram}

Türk Dil Kurumu [TDK] resmî Internet sitesindeki çevrimiçi sözlükte kavram kelimesi, "bir nesnenin veya düşüncenin zihindeki soyut ve genel tasarımı, mefhum, fehva, konsept, nosyon" şeklinde tanımlanmaktadır (TDK, 2021). Kavram kelimesinin tanımı 
hususunda alan yazın oldukça zengindir. Bunlardan birkaçı şöyledir; Kavramlar birer nesne değil de düşünce olarak bilinmelidirler. Bir varlığın akılda kalan izlerine kavram denir (Çepni ve Ayas, 2005). İnsanların, düşüncelerin, olayların ve nesnelerin benzerliklerine göre sınıflandırıldığında meydana gelen gruplara kavram denir. Öte yandan, insan-dünya ilişkisini gösteren tanım ve sinıflara ait niteliklerdir.

Daha kapsamlı bir ifadeyle kavram terimi dünyada olup biten her şeye anlam kazandırmak demektir. Kavramların nasıl nitelediğine ve neyi nitelediğine dair anlamsal olarak incelemeler yapılmıştır. Örneğin, foton (1şık parçacığı) kavramını anlayabilmek için 1şığın hareketlerini de bilmek gerekir. (YÖK/Dünya Bankası, 1997; Riche, 2000).

\section{Önyargı}

Önyarg1, bir öğrencinin eğitim hayatına başlamadan önce öğrendiği belli bir konudaki kavramları ifade eder. Ancak tüm önyargıları kavram yanılgıları olarak görmek doğru değildir (Clement, 1993). Kavram terimi "sınıflandırma" ve "öğrenilen bilgi” olmak üzere iki şekilde ifade edilebilir. İlki, bir şeyin herhangi bir yere ait olup olmadığına bakılmaksızın nesneleri kategorize edebilme yeteneğidir. İkinci ifade şekli ise bir kişinin sahip olduğu ve kavram olarak ilişkilendirdiği bütün bilgilerdir. Kısaca kavramlar oldukça karmaşık ve tanımlanması zor olan ifade sistemleri olarak tanımlanabilir (White, 1994). Başka bir deyişle önyargı, öğrencilerin önceden yaşadıkları çevrede tecrübe edindikleri görüş, fikir ve tutumlarından oluşan kavramlardır. Öğrenciler yakın çevrelerini keşfederlerken karşılaştıkları yeni olayları kendi ürettikleri kavramlarla açıklamaya çalışırlar ve bunu da başkalarıyla paylaşırlar. $\mathrm{Bu}$ şekilde önyargılarla yanlış kararlar vermeye sebep olan sezgiler ve düşünceler kavram yanılgılarına dönüşmüş olmaktadırlar (Riche, 2000).

\section{Kavram Yanılgisı}

Alan yazında yapılan tanıma göre kavram yanılgısı, bilimsel olarak kabul edilen kuramlarla çelişen bir ön yargıdır (Clement, 1993). Önceki araştırmalar çok çeşitli yaş ve eğitim geçmişine sahip öğrencilerin birçok fizik kavramı hakkında yanlış kanıya sahip olduklarını göstermektedir. Sadece sıradan öğrenciler değil, üstün başarılı öğrenciler ve hatta fizik öğretmenleri bazı fizik kavramlarını çok yanlış anlamaktadırlar. Kavram yanılgılarından kurtulmak çok zor ve önemsenmesi gereken bir olgudur. Aksi takdirde öğrenilen yanlış kavramlar, zihne yerleşerek çoğalır ve kavramsal anlamayı olumsuz etkileyen kalıcı sorunlar oluştururlar (Ery1lmaz, 2002). 
İnsanlar birtakım gözlemler yaptıktan sonra, bu gözlem sonuçlarını genelleme yapmayı tercih ederler. Bu genellemeler sonucunda oluşan parçalara kavram adı verilir (Kaptan, 1999). Kavram, insanları mevcut bilgileri kullandırmaya sevk eden ve onları anlamlı hale getiren zihinsel bir mekanizmadır (Senemoğlu, 2004). Öğrenme, çevresel şartlara bağl1 olarak insanların tutum ve davranışlarındaki değişimdir. Kavram öğrenme ise uyarıcıları sınıflandırarak zihinde onlarla ilgili bilgi üretme işlemidir (Ülgen, 2001).

Öğrencilerin fen bilimleri ile ilgili kavram yanılgıları, bilimsel araştırmalarda yıllardan beri güncelliğini ve önemini koruyan bir konudur (Yanarateş, 2021). Fen bilimleri öğretmenleri öğrencilerdeki kavram yanılgıları hususunda şu sorulara cevap aramaktadırlar; “Kavram yanılgısı nedir?”, "Sadece bir yanlış anlama mıdır?”, “Kavram yanılgısı ile önyargı arasındaki farklılık nedir?”, "Kavram yanılgıları çeşitlilik gösterir mi?” “Öğrencilerin kavram yanılgıları ile bir fen bilimleri öğretmeninin aktivitesi arasında bir ilişki var mıdır, varsa bağlantısı nedir?” (Riche, 2000; Yağbasan ve Gülçiçek, 2003). Öğrenim hayatının daha ilk yıllarında meydana gelebilecek olan kavram yanılgıları sonraki yıllarda da öğrenmeleri üzerinde olumsuz etki bırakacaktır. Bu sebeple öğretmenler anlatacakları dersleri hazırlarken öğrencilerde oluşan kavram yanılgılarını dikkate almalıdırlar (Nakiboğlu ve Özkılıç, 2005).

Kavram yanılgıları bazen toplumda bir suç gibi algılanmakta ve kimse yanılgıya düşebileceğini kabul etmemektedir. Su kirliliği ile ilgili yapılan bir çalışmada araştırmaya dahil olan öğrencilerin aleyhte çıkan sonuçtan, kendilerine verilen eğitim-öğretimin bütün kademelerindeki ders içeriklerini sorumlu tuttukları gözlenmiştir. Yani konuyla ilgili hemen herkes olumsuz bir katkıda bulunmasına rağmen hiç kimse kabahati kendinde görmemektedir. Dahası yaptıkları hataları gizlemek için sürekli olarak birilerini sorumlu tutmaktadırlar (Yılmaz ve Yanarateş, 2020). Bu nedenle bireylere kavram yanılgısı ile ilgili farkındalıkların da verilmesi gerekmektedir.

Kavram yanılgılarını ortadan kaldırmak için ilk önce öğrencilerde hangi konularda kavram yanılgıları olduğunu belirlemek gerekir (Yılmaz ve Bayrakçeken, 2017). Ayrıca öğrencilere daha önceki bilgilerini tekrar gözden geçirmelerine yardım edilmelidir. Daha sonra öğretmenler tarafından söz konusu öğrencilerin var olan kavram yanılgıları ile yüzleştirilmeleri etkili olacaktır. Tabi bunun için belli bir sürece ihtiyaç vardır. Öğretmenlerin bu süreci çok dikkatli bir biçimde takip etmeleri gerekir (Ecevit ve Şimşek, 2017). 


\section{İçerik analizi}

İçerik analizi genellikle nitel araştırma metotlarının özelliklerini taşıyan bir araştırma tekniğidir. Aynı zamanda bu yöntem, birtakım olay veya etkinliklerle ilgili bilgilerin bulunduğu yazılı kaynakların analizi şeklinde ifade edilen doküman incelemesidir (Batd1, 2019). Doküman inceleme kavramı herhangi bir araştırma tekniği mi yoksa bilimsel araştırma tekniğinin bir parçası olan veri toplama aracı mı noktasında bazen kafaları karıştırmaktadır. Bu karışıklık muhtemelen dokuman inceleme kavramının hem bir yöntem hem de bir analiz çeşidi olarak kullanılmasından kaynaklanmaktadır (Özkan, 2019).

İçerik analizi/doküman incelemesi yöntemi, çeşitli araştırmalardan toplanarak bir araya getirilen verileri açıklamaya yetecek kadar bilgiye ve bağlantılara ulaşma tekniğidir. Betimsel analizde yüzeysel olarak işlenen veriler, içerik analizinde daha ayrıntılı olarak değerlendirilmektedir. Böylece betimleme yaklaşımıyla yapılan analizde gözden kaçabilecek bazı kavramlar, içerik analiziyle temalar halinde bir araya getirilerek okuyucuların daha kolay anlayabilecekleri şekilde yorumlanmaktadır.

İçerik analizi tekniğine dayanan çalışmalarda, çoğunlukla "Nasıl? Niçin? ve Ne?” gibi sorulara cevap bulmaya çalışılır. Bu yöntemin esas amac1; bazı genel kuramların aydınlatılması için incelemeye alınan örnek olayların detaylı bir şekilde tanıtılmasıdır. Örnek olayla ilgili inceleme çalışmaları, anket, mülakat, doküman analizi ve gözlem gibi araştırma yöntemlerinin hemen hepsini kapsayan bir yelpaze olarak tanımlanabilir. Bu çalışmalarda elde edilen veriler sistemli bir biçimde toplanarak değişkenler arasında bağlantı kurulmaya çalışılır. Örnek olayla ilgili araştırmaların amacı genellikle ispat ve faktörlerin birbirleri arasındaki ilişkilerin incelenmesi şeklindedir. $\mathrm{Bu}$ tür araştırmaların üzerinde yoğunlaştığı nokta, sebep-sonuç ilişkisine dayanmaktadır (Çepni, 2018).

$\mathrm{Bu}$ çerçevede literatürde fen bilimleri eğitimindeki kavram yanılgıları ile ilgili neler yapıldığı, nü tür eksikliklerin bulunduğu ve alana ne tür katkılar sağladığı gibi konuların tespit edilmesi ve kavram yanılgılarının azaltılması yönünden önemli bulunmaktadır (Yavuz, 2017; Bağ ve Çalık, 2018). Bu vesileyle alan yazına sunulacak olan bu araştırmadaki bulgularla ilgili çalışmalar yapacak olan araştırmacıların, söz konusu alanla ilgili tematik bilgileri toplu olarak bir arada bulacakları için aynı bilgili tekrar aramalarına gerek kalmayacağı ve kendilerine önemli ölçüde zaman kazandıracağı düşünülmektedir. Bir şekilde bu çalışmayla karşılaşan araştırmacıların ise makaledeki bulguları, sonuçları ve önerileri görerek konuyla ilgili bilgi sahibi olmaları beklenmektedir. 
Fen bilimleri eğitiminde karşılaşılan kavram yanılgıları ile ilgili Türkiye'de son 20 yılda yapılmış olan doktora ve yüksek lisans tezlerine ait içerik analizlerinin konuyla ilgili eğilimini tespit etmek bakımından önemli olduğu düşünülmektedir. Öte yandan alan yazında, Türkiye'de fen bilimleri eğitiminde karşılaşılan kavram yanılgılarına ilişkin kapsamlı bir araştırmaya rastlanmamıştır.

Konuları anlamada kavram yanılgılarının giderilmesi gerektiği düşünülürse, konuyla ilgili yapılan araştırmaların türleri, vardıkları sonuçlar ve yaptıkları öneriler oldukça önem kazanmaktadır. Öğrencilerin fen bilimleri eğitimindeki kavram yanılgılarını gidermek ve bununla ilgili çalışmalar yapmak için literatürde ne tür araştırmaların yapıldığı ve fen bilimleri alanında ne tür eksikliklerin bulunduğu tespit edilmelidir. Bu beklentiler 1şı̆̆ında çalışmanın amacı; Türkiye'de fen bilimleri eğitiminde karşılaşılan kavram yanılgılarına ilişkin lisansüstü tezlerin tematik içerik analizinin kapsamlı bir şekilde incelenmesidir. Bunun için YÖK-Ulusal Tez Merkezi resmî Internet sitesi kayıtlarında izinli bulunan ve isimlerinde "fen" ve "kavram yanılgıları" anahtar kelimelerinin birlikte geçtiği tezlerin tamamı kullanılmıştır. Dolayısıyla çalışmanın örneklemi 2001-2020 yılları arasında yapılmış olan 136 tane izinli tezden oluşmaktadır.

\section{Araştırmanın Amacı}

Bu çalışmada 2001-2020 yılları arasında Türkiye'de yapılan fen bilimleri eğitiminde karşılaşılan kavram yanılgılarına iliş̧in yüksek lisans ve doktora tezlerinin, yayın yılları, yazım dilleri, yayımlandığı enstitüler, amaçları, araştırma konuları, araştırma yöntemleri, veri analiz yöntemleri, örneklemleri (çalışma grupları), örneklem sayıları, veri toplama araçları, sonuçlar ve önerilerden oluşan temaların sınıflandırılması nasıldır? Bu amaçla aşağıdaki sorulara cevaplar aranmıştır.

Fen bilimleri eğitiminde karşılaşılan kavram yanılgılarına ilişkin;

1. Tezlerin sayısı yıllara göre nasıl değişmektedir?

2. Tezler yazım dillerine göre nasıl değişmektedir?

3. Tezlerin yayımlandıkları enstitülerin dağılımı nasıldır?

4. Tezlerin amaçları genel olarak nelerdir?

5. Tezlerde ne tür konular araştırılmıştır?

6. Tezlerde hangi araştırma yöntemleri kullanılmıştır?

7. Tezlerde hangi veri analiz yöntemleri kullanılmıştır?

8. Tezlerin örneklemleri (çalışma grupları) nelerdir? 
9. Tezlerin örneklem sayıları nasıl değişmektedir?

10. Tezlerde hangi veri toplama araçları kullanılmıştır?

11. Tezlerde ne tür sonuçlar bulunmuştur?

12. Tezlerde ne tür öneriler sunulmuştur?

Araştırmadaki bazı alt problemlerin cevapları ayrıntılı ve tematik olarak ayrıca "Ekler" kısmında verilmiştir. Söz konusu temalar, tez türlerine, yayın yıllarına, yayımlandıkları enstitülere, yazım dillerine ve tez kimlik numaralarına göre sınıflandırılmıştır (Ek 1-2). Bunların dışında kalan alt problemler ve cevapları "Bulgular" bölümünde incelenmiştir.

\section{Yöntem}

Betimsel araştırma yöntemlerinden tarama modeli kullanılarak yapılan bu araştırmada, Türkiye'de fen bilimleri eğitimi kapsamında yapılan kavram yanılgıları ile ilgili çalışmaların ele alındığı betimsel içerik analizi yöntemi kullanılmıştır. $\mathrm{Bu}$ yöntem, nicel ve nitel araştırmalardan oluşan ve birbirleriyle benzer konuları inceleyen çalışmaların temaları belirlenerek yapılan sentez ve yorumlama faaliyetleridir (Çalık ve Sözbilir, 2014). İçerik analizi konusunda birtakım yanılgılar ortaya çıkabilmektedir. $\mathrm{Bu}$ yanılgıların sebebi muhtemelen içerik analizi kavramının bazen "araştırma yöntemi" bazen de "veri analiz yöntemi” şeklinde ifade edilmesidir. Dolayısıyla bu yanılgılar çoğu zaman araştırmayı nicelnitel olarak sınıflandırma eğiliminde olan çelişkilere sebep olabilmektedir.

Betimsel içerik analizi, genel durumu göstermekle ilgilenen ve belirli temaların frekans ve yüzdelerini kullanarak konuyla ilgili genel bilgiler veren bir yöntemdir. $\mathrm{Bu}$ yöntemde ayrıntılı yorumlara yer verilmemektedir (Dinçer, 2018). Başka bir deyişle, bilimin tasvir etme işlevini ön plana çıkaran tematik içerik analizinde temel prensip, literatür taranmasıyla elde edilen verilerin, önceden belirlenmiş olan kavram ve tema çerçevesinde birbirine benzeyenleri sınıflandırmak ve anlaşılabilir bir şekilde düzenleyerek yorumlamaktır (Yıldırım ve Şimşek, 2018).

Betimsel içerik analizi çoğunlukla araştırmanın genel hatlarına ilişkin bilgiler vermeyi hedeflerken, tematik içerik analizinde ise odaklanılan çalışma sayısı daha az olduğu için daha detaylı bilgiler verilmektedir (Çepni, 2018). Bu çalışmada da Türkiye'de fen bilimleri eğitimi kapsamında yapılan kavram yanılgıları ile ilgili çalışmaların birer birer incelenmesi ve temaların tespit edilmesi hedeflendiğinden tematik içerik analizi uygun görülmüştür. 


\section{Verilerin Toplanması}

$\mathrm{Bu}$ çalışmaya veri teşkil edecek olan araştırmalar için Ulusal Tez Merkezi veri tabanına ait https://tez.yok.gov.tr web adresindeki konuyla ilgili yüksek lisans ve doktora tezlerine ulaşılmıştır. Taramalar yapılırken "fen” ve "kavram yanılgıları" ifadeleri aynı tez adında geçecek şekilde anahtar kelimeler kullanılmıştır. En son tez taramaları 5 Ocak 2021 tarihinde yapılmıştır. Yapılan bütün taramalara rağmen "Türkiye'de fen bilimleri eğitiminde karşılaşılan kavram yanılgılarına ilişkin tezler" gözümüzden kaçmış olabilir. Yapılan taramalar sonucunda konuyla ilgili olarak 20 tane doktora tezi ve 116 tane yüksek lisans tezinden oluşan toplam 136 tane izinli teze ulaşılmıştır. Araştırmada fen bilimleri eğitimi alanında yapılan tezlerin incelenmesi ve genel eğilimin tespit edilmesi amaçlandığ için yöntem olarak doküman inceleme/tematik içerik analizi kullanılmıştır.

\section{Bulgular}

Araştırma örneklemindeki doktora ve yüksek lisans tezleri belirlenen alt problemler doğrultusunda incelenmiştir. İnceleme sonucunda toplanan veriler tematik olarak sınıflandırılarak elde edilen bulgular tematik olarak on iki bölüm halinde sunulmuştur.

\section{Araştırılan tezlerin "Yayın yılı" temaları}

Çalışmanın amacında ve alt problemlerinde belirtildiği gibi tezlerin yıllara göre nasıl değiştiği incelenmiştir. Yayımlama yılları ile ilgili veriler Şekil 1'de gösterilmiştir.

Ulusal Tez merkezi kayıtlarına göre fen bilimleri eğitimi kapsamında kavram yanılgıları ile ilgili olarak 2001'den önce yapılmış toplam 3 tane lisansüstü tez bulunmaktadır. Bunlar da zaten araştırma izni olmayan yüksek lisans tezleridir. Dolayısıyla izinli tezler kapsamında bu çalışma, fen bilimleri eğitiminde karşılaşılan kavram yanılgılarına ilişkin günümüze kadar yapılmış olan bütün lisansüstü tezleri kapsamaktadır (Ek 1-2). 


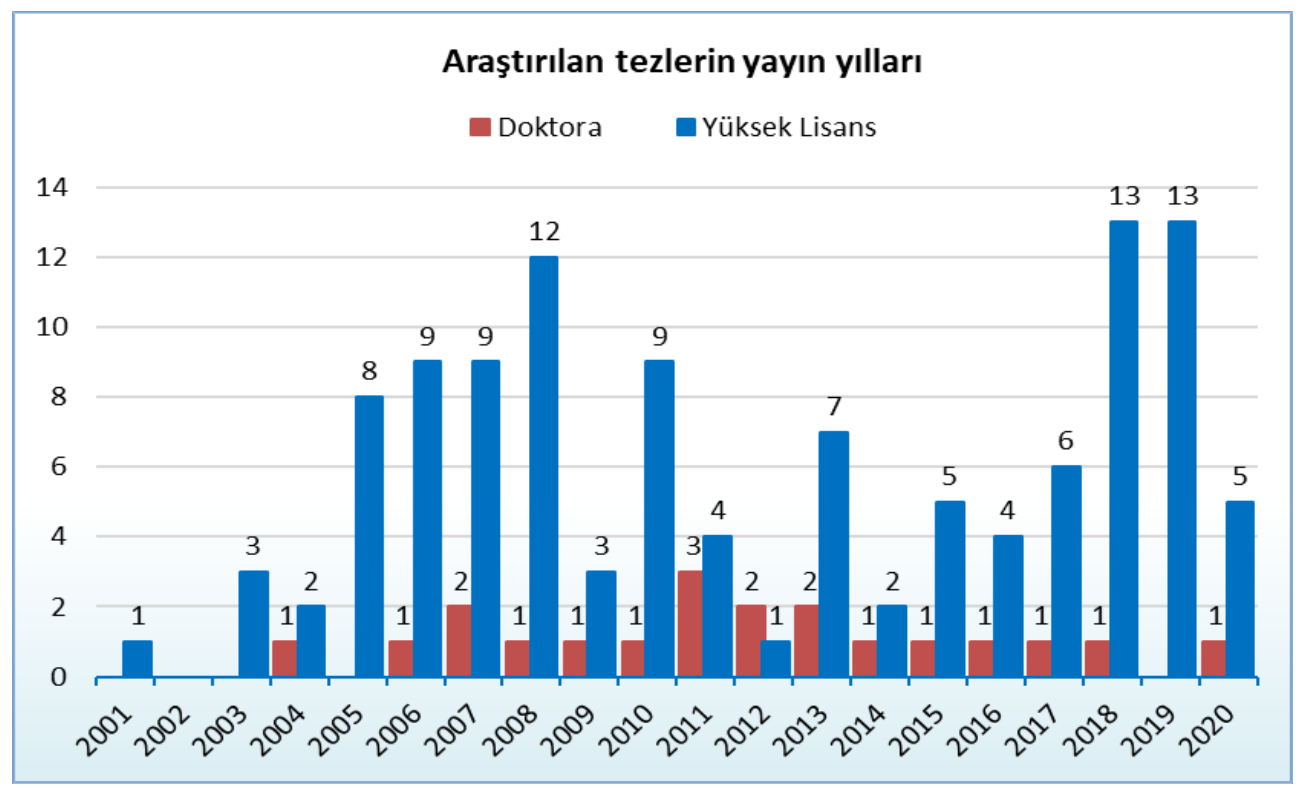

Şekil 1. Araştırılan tezlerin yayın yıllarına göre dağılımları

Şekil 1'de görüldüğü gibi 2001-2020 yılları arasında fen bilimleri eğitimi kapsamında kavram yanılgılarına ilişkin doktora seviyesinde çok fazla tez bulunmamaktadır. Özellikle de 2000’li yılların başında konuyla ilgili tamamlanmış bir doktora tezine rastlanmamıştır. 20112013 yılları arasında biraz hareketlense de son yıllarda doktora seviyesinde kavram yanılgıları konusuna karşı ilginin tekrar azaldığı görülmektedir. Bunun yanında en fazla 2018 ve 2019 yıllarında toplam 26 yüksek lisans tezi tamamlanmıştır. Ancak 2020 yılında yüksek lisans tezlerinde de kavram yanılgıları konusuna karşı ilginin azaldığı gözlenmiştir.

\section{Araştırılan tezlerin "Yazım dili" temaları}

Alt problemlerde belirtildiği gibi araştırılan tezlerin yazıldıkları dillere göre nasıl dağılım gösterdikleri incelenerek ve elde edilen bulgular Şekil 2'de gösterilmiştir.

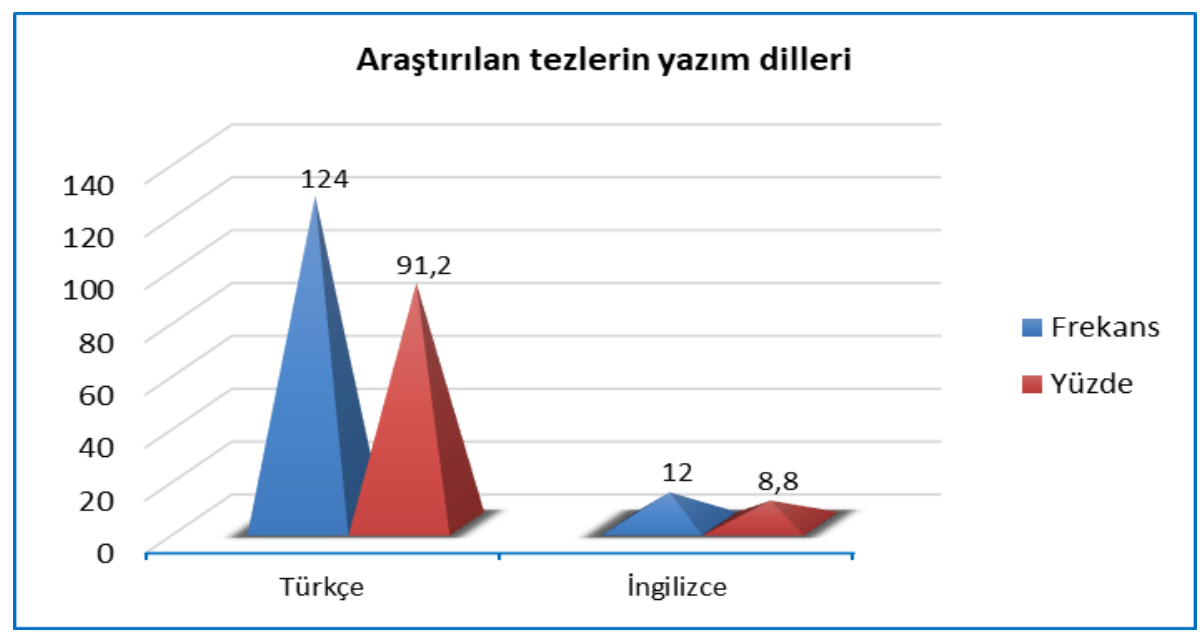

Şekil 2. Araştırılan tezlerin yazım dillerine göre frekans dağılımları 
Fen bilimleri eğitiminde kavram yanılgılarına ilişkin tezlerin yazım dili incelendiğinde 124 (\%91) tezle araştırmaların çoğunluğunun Türkçe dilinde yazıldığı gözlenmektedir. Geri kalan $12(\% 9)$ tez ise İngilizce dilinde yazılmıştır. İngilizce olarak yazılmış tezler ya tamamen İngilizce öğretim veren ya da hem Türkçe hem de İngilizce öğretim veren üniversitelere ait enstitülerde yayınlandığı görülmüştür. Tezlerin büyük bir bölümünün Türkçe yazılmış olması Türkiye'deki üniversitelerin çoğunda Türkçe eğitim-öğretim verildiğinden kaynaklıdır.

\section{Araştırılan tezlerin "Yayınlandıkları enstitüler" temaları}

Alt problemlerde belirtildiği gibi araştırılan tezlerin yayınlandığı enstitülere göre nasıl dağılım gösterdikleri incelenerek ve elde edilen bulgular Şekil 3 ’te gösterilmiştir.

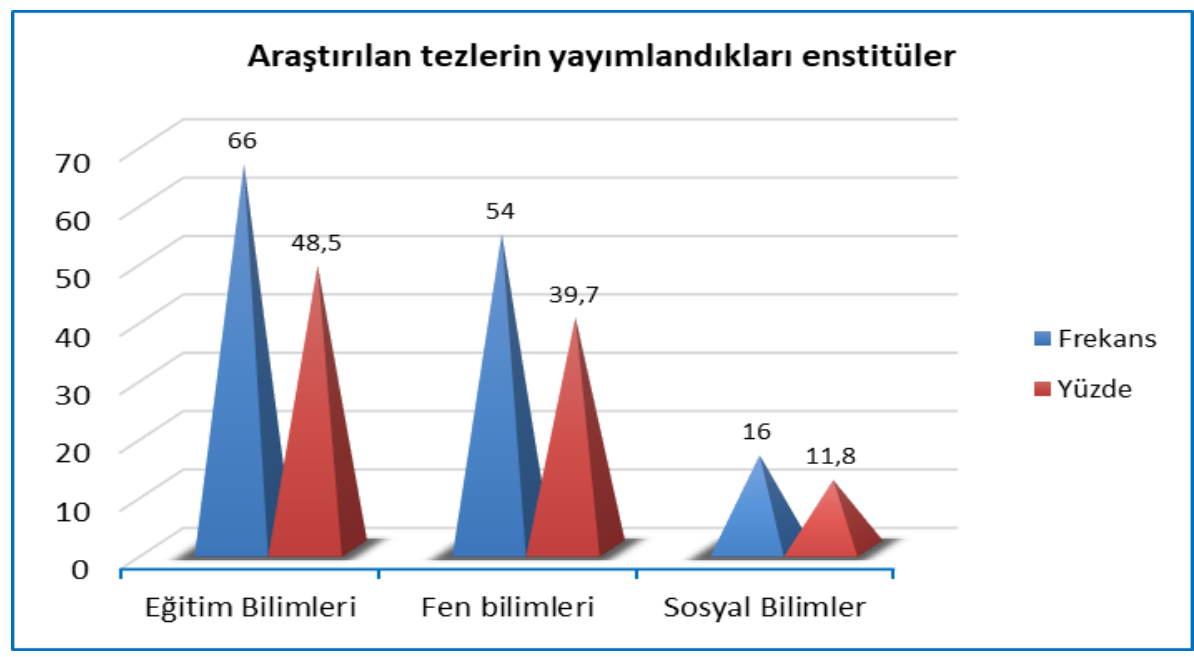

Şekil 3. Araştırılan tezlerin yayımlandıkları enstitülere göre frekans dağılımları

Şekil 3'e göre araştırılan tezlerin yayımlandıkları enstitülerden $66(\% 49)$ tezle eğitim bilimleri enstitüleri başı çekerken, onu $54(\% 40)$ tezle fen bilimleri enstitüleri takip etmektedir. En son sırayı $16(\% 12)$ tezle sosyal bilimler enstitüleri almaktadır.

"Fen bilimleri eğitiminde kavram yanılgıları" konusunun fen ve eğitim kelimelerini içerdiği dikkate alındığı zaman en az tez yayınlanan enstitülerin sosyal bilimler olması normal karşılanmaktadır. Yine normal karşılanacağı üzere diğer iki enstitünün oranları da birbirine yakindir.

\section{Araştırılan tezlerin "Araştırmanın amacı" temaları}

Alt problemlerde belirtildiği gibi araştırılan tezlerin amaçlarına göre nasıl dağılım gösterdikleri incelenerek ve elde edilen bulgular Şekil 4'te gösterilmiştir. 


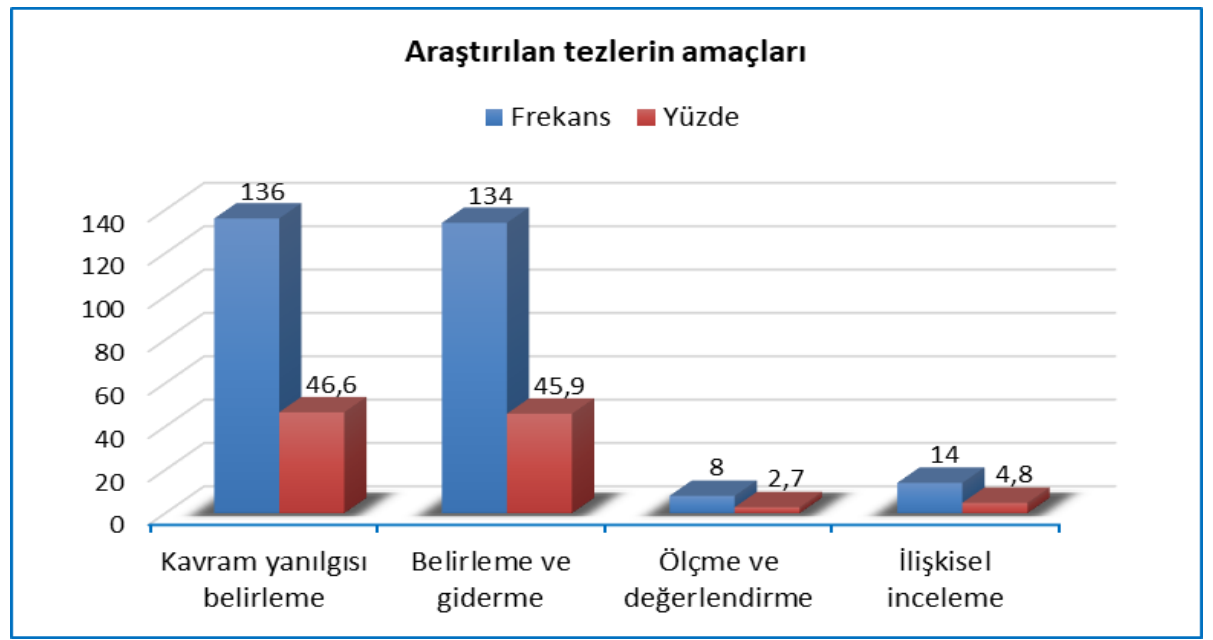

Şekil 4. Araştırılan tezlerin amaçlarına göre frekans dağılımları

Bazı tezlerde birden fazla araştırmanın amacı ele alınmıştır.

Şekil 4'e göre, araştırılan tezlerin hemen hemen tamamı $270(\% 92,5)$ hem kavram yanılgısı belirlemek hem de müdahale sonucunda kavram yanılgısını gidermek amaciyla yapılmıştır. Bunun yanında tezlerin $8(\% 2,7)$ tanesi aynı zamanda ölçme ve değerlendirme, 14 $(\% 4,8)$ tanesi de aynı zamanda ilişkisel inceleme amacıyla hazırlanmıştır.

Tezlerin neredeyse tamamının "kavram yanılgısı belirleme" ve "kavram yanılgısını belirleme giderme" amaçlı hazırlanması normal karşılanmaktadır.

\section{Araștırılan tezlerin "Araștırmanın konusu" temaları}

Alt problemlerde de belirtildiği gibi araştırma konularına göre tezlerin nasıl dağıldığı incelenerek, elde edilen bulgular Şekil 5 'te gösterilmiştir.

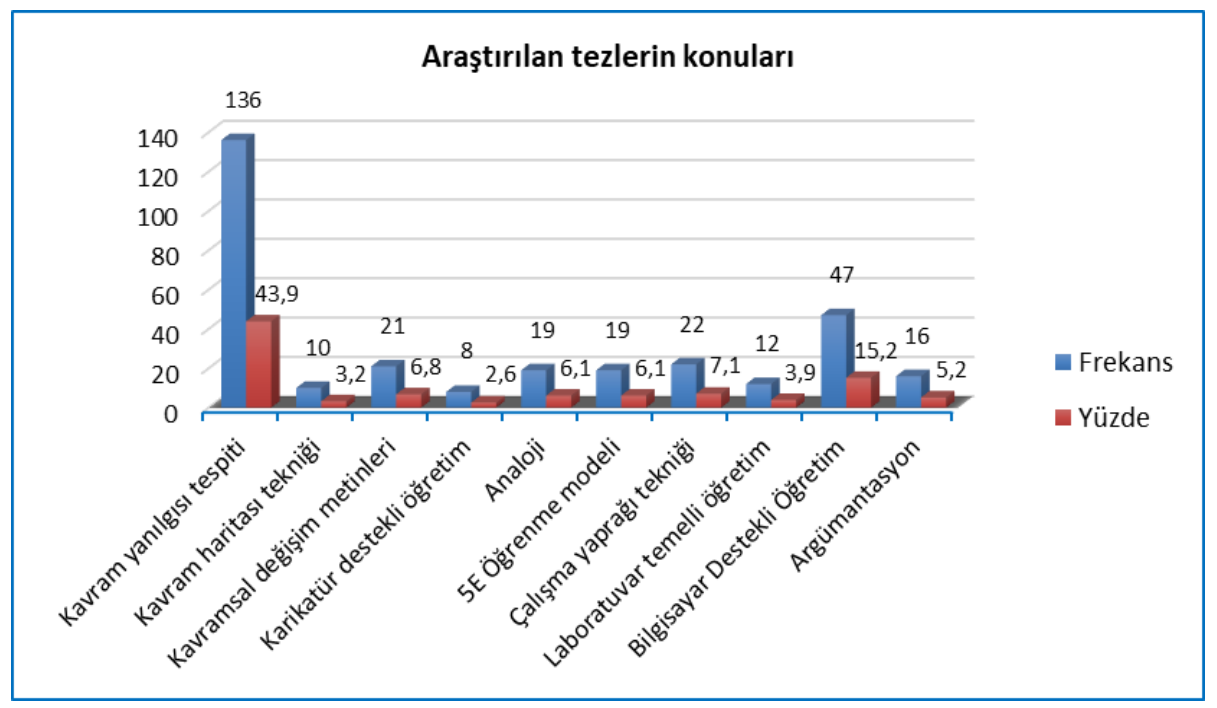

Şekil 5. Çalışılan tezlerin araştırma konularına göre frekans dağılımları

Bazı tezlerde birden fazla konu ele alınmıştır. 
Van YYÜ Eğitim Fakültesi Dergisi (YYU Journal of Education Faculty),2022:Şubat Özel Sayı 182-213,http://efdergi.yyu.edu.tr,

Şekil 5'e göre araştırılan 136 (\%44) tezin tamamında "kavram yanılgısı tespiti" konusu çalışılmıştır. Bu araştırma konusunun yanında ikinci veya üçüncü bir araştırma konusu daha hedeflenmiştir. Bu durumda ikinci sırada 47 (\%15) tezle son y1llarda giderek önemi daha da artan "Bilgisayar Destekli Öğretim” konusu yer almaktadır. Araştırılan tezlerin geri kalanında ise araştırma konularının dağlımı sırasıyla şöyledir; $10(\% 3,2)$ tezde "kavram haritası tekniği", $21(\% 6,8)$ tezde "kavramsal değisşim metinleri", $8(\% 2,6)$ tezde "karikatür destekli öğretim”, $19(\% 6,1)$ tezde "analoji”, $19(\% 6,1)$ tezde "5E öğrenme modeli”, 22 $(\% 7,1)$ tezde "çalışma yaprağı tekniği”, $12(\% 3,9)$ tezde "laboratuvar temelli öğretim" ve 16 $(\% 5,2)$ tezde ise "Argümantasyon” konusu üzerinde durulmuştur.

\section{Araştırılan tezlerin "Araştırma yöntemi" temaları}

Alt problemlerde belirtildiği gibi araştırılan tezlerin araştırma yöntemleri, desenleri (yaklaşımları) ve dağılımları incelenerek elde edilen bulgular Şekil 6'da gösterilmiştir.

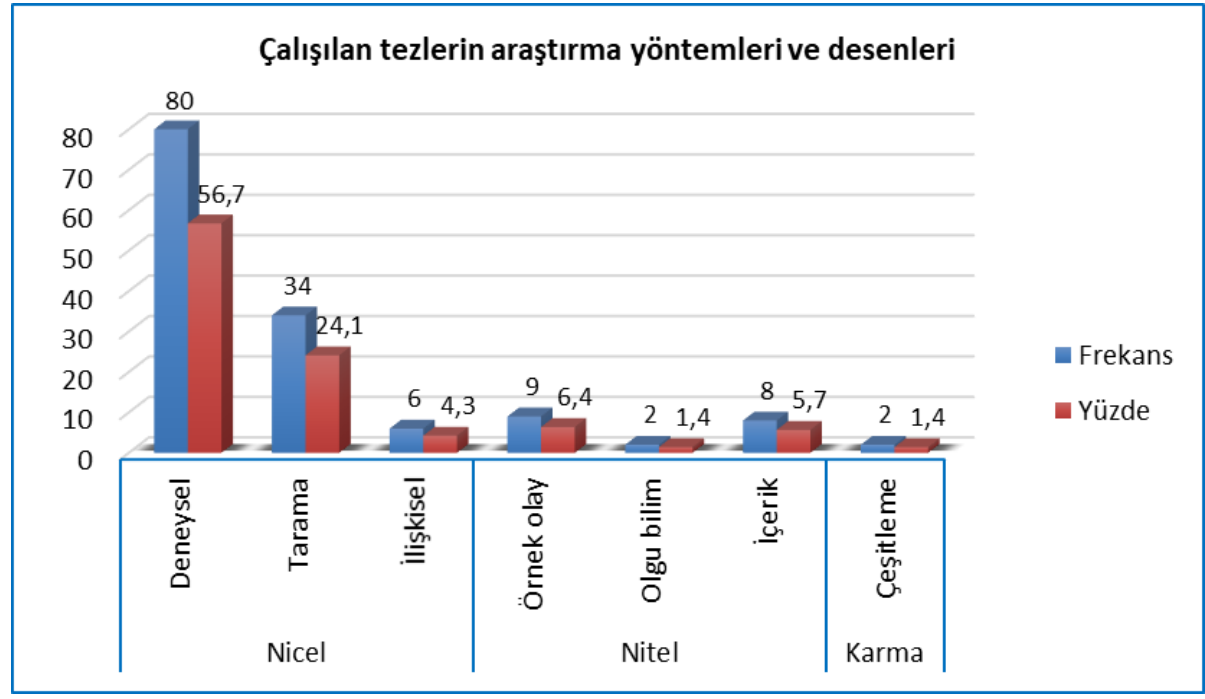

Şekil 6. Çalışılan tezlerin araştırma yöntemlerine ve desenlerine göre frekans dağılımları

Bazı tezlerde birden fazla araştırma yöntemi kullanılmıştır.

Şekil 6'ya göre araştırılan tezlerin çoğunda nicel araştırma yöntemleri kullanılmıştır. Desenlerine göre bu çalışmalar $80(\% 56,7)$ tezle birinci sırada yer alan "Deneysel”, 34 $(\% 24,1)$ tezle ikinci sırada yer alan "Tarama" ve $6(\% 4,3)$ tezle beşinci sırada yer alan “İlişkisel” yöntemlerdir. İncelenen tezlerin geri kalanında ise nitel ve karma araştırma yöntemlerinin kullanıldığı gözlenmiştir. Desenlerine göre bu çalışmalarda kullanılan araştırma yöntemleri ise sırasıyla şu şekildedir; $9(\% 6,4)$ tezle "Örnek olay", 8 (\%5,7) tezle "İçerik", 2 $(\% 1,4)$ tezle "Olgu bilim” ve $2(\% 1,4)$ tezle "Karma (çeşitleme)" araştırma desenleridir. 


\section{Araştırılan tezlerin "Veri analizi" temaları}

Alt problemlerde belirtildiği gibi araştırılan tezlere ait veri analizleri ve dağılımları incelenerek elde edilen bulgular Şekil 7'de gösterilmiştir.

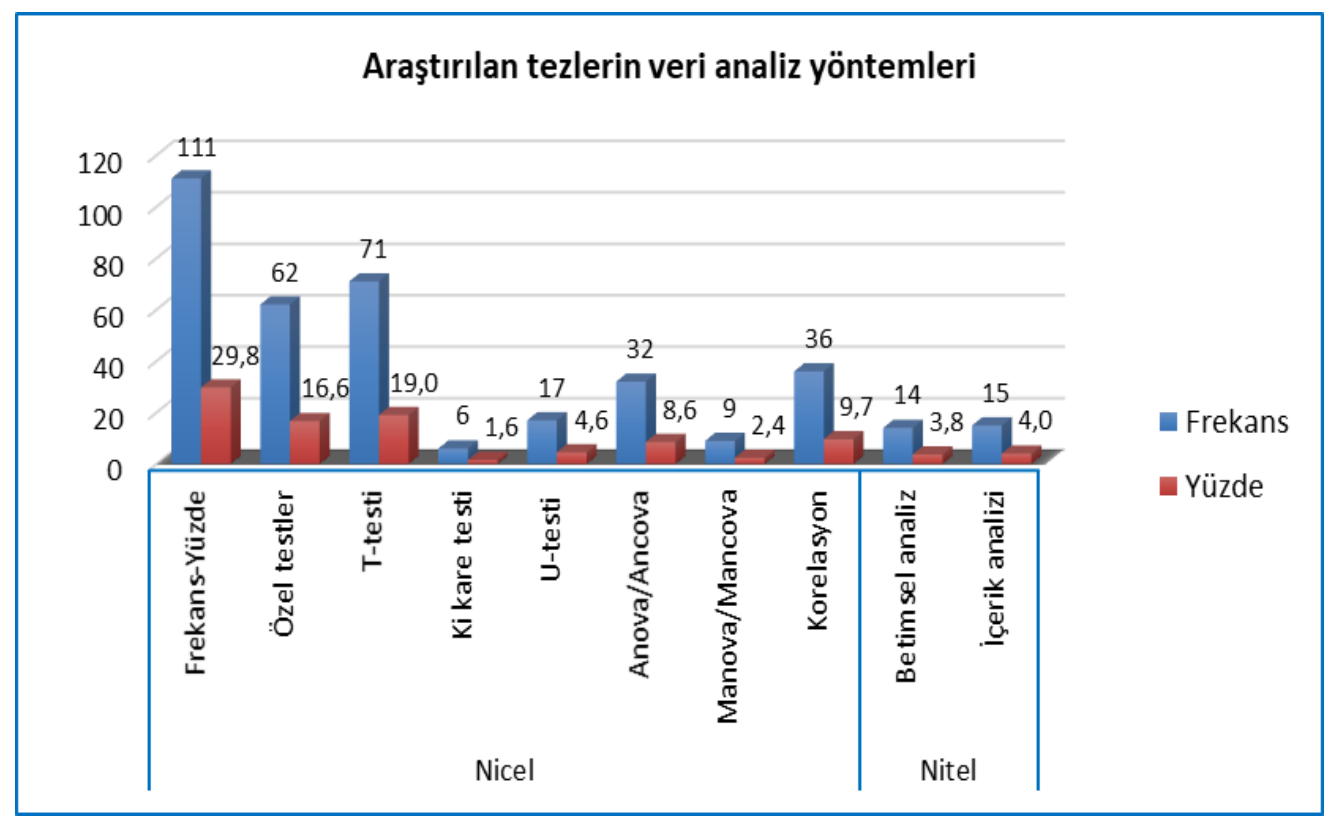

Şekil 7. Araştırılan tezlerin veri analiz yöntemlerine göre frekans dağılımları

Bazı tezlerde birden fazla veri analiz yöntemi kullanılmıştır.

Şekil 7’ye göre çalışılan tezlerin çoğunda veri analiz yöntemi olarak nicel analizlerin tercih edildiği dikkat çekmektedir. Veri analiz yöntemlerine göre bu çalışmalar $111(\% 29,8)$ tezle birinci sırada yer alan "Frekans-yüzde” yöntemidir. Geri kalan çalışmaların veri analiz yöntemlerine göre dağlımı sırasıyla şöyledir; 62 (\%16,6) tezde “Özel testler” (kavram yanılgılarını gidermeye yönelik olarak tezleri hazırlayan kişiler tarafından değişik isimler altında geliştirilen testler), 71 (\%19,0) tezde “T-testi”, $6(\% 1,6)$ tezde "Ki kare testi”, 17 (\%4,6) tezde "U-testi”, $32(\% 8,6)$ tezde “Anova/Ancova”, 9 (\%2,4) tezde "Manova/Mancova” ve $36(\% 9,7)$ tezde ise "Korelasyon" analizleri kullanılmıştır. Nitel analiz yönteminin tercih edildiği son iki analiz türü ise $14(\% 3,8)$ tezle "Betimsel" ve $15(\% 4,0)$ tezle ise "İçerik" analizleridir.

\section{Araştırılan tezlerin "Evren ve örneklem" temaları}

Alt problemlerde belirtildiği gibi araştırılan tezlerin örneklemleri (çalışma grupları) ve dağılımları incelenerek elde edilen bulgular Şekil 8'de gösterilmiştir. 
Van YYÜ Eğitim Fakültesi Dergisi (YYU Journal of Education Faculty),2022:Şubat Özel Sayı 182-213,http://efdergi.yyu.edu.tr,

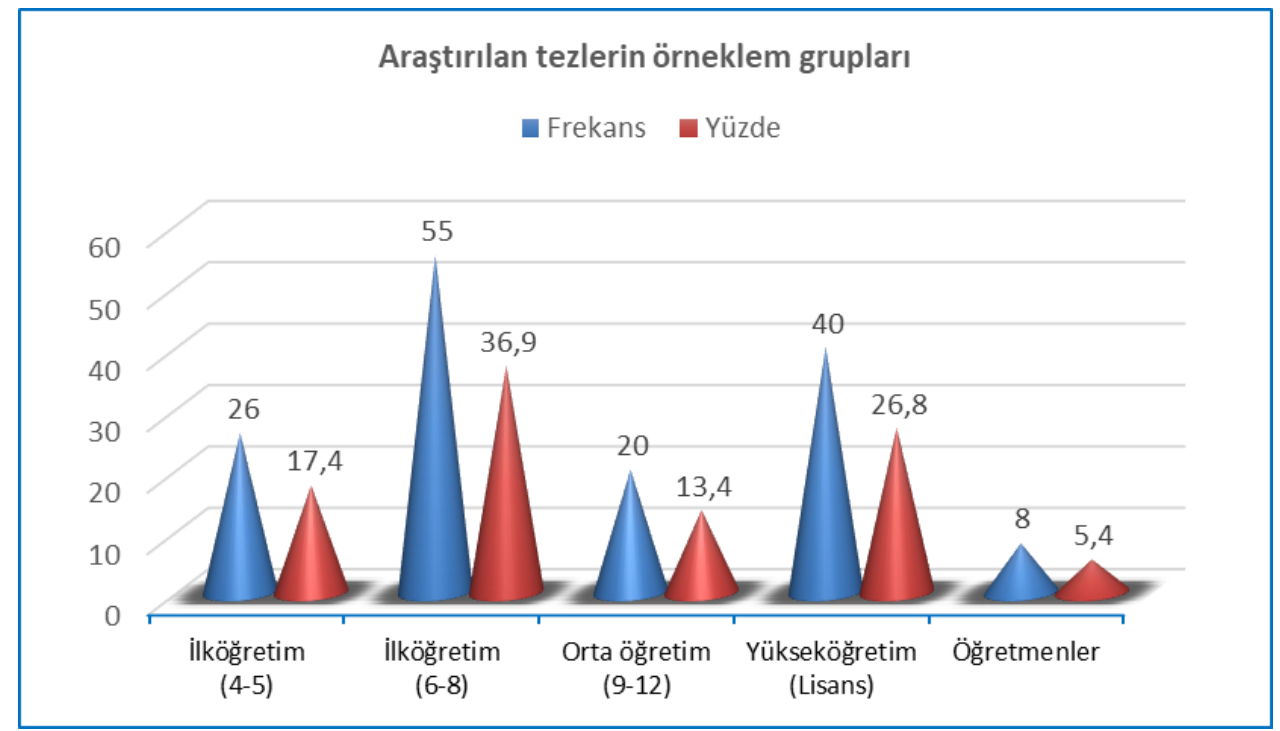

Şekil 8. Araştırılan tezlerin örneklem gruplarına göre frekans dağılımları

Bazı tezlerde birden fazla örneklem grubu ile çalışılmıştır.

Şekil 8’e göre, araştırılan tezlerin çoğunun 55 (\%36,9) tezle “İlköğretim (6-8)" örneklem grubuyla çalıştığı gözlenmiştir. Bunu takip eden diğer çalışmaların örneklem gruplarına göre dağılımı ise sırasıyla şu şekildedir; 26 (\%17,4) tezle “İlköğretim (4-5)”, 20 $(\% 13,4)$ tezle “Orta öğretim $(9-12)$ ”, 40 (\%26,8) tezle "Yükseköğretim (Lisans)” ve $8(\% 5,4)$ tezle “Öğretmenler” den oluşan çalışma gruplarıdır.

\section{Araştırılan tezlerin "Örneklem sayısı" temaları}

Alt problemlerde belirtildiği gibi araştırılan tezlerin örneklem sayıları ve dağılımları incelenerek elde edilen bulgular Şekil 9'da gösterilmiştir.

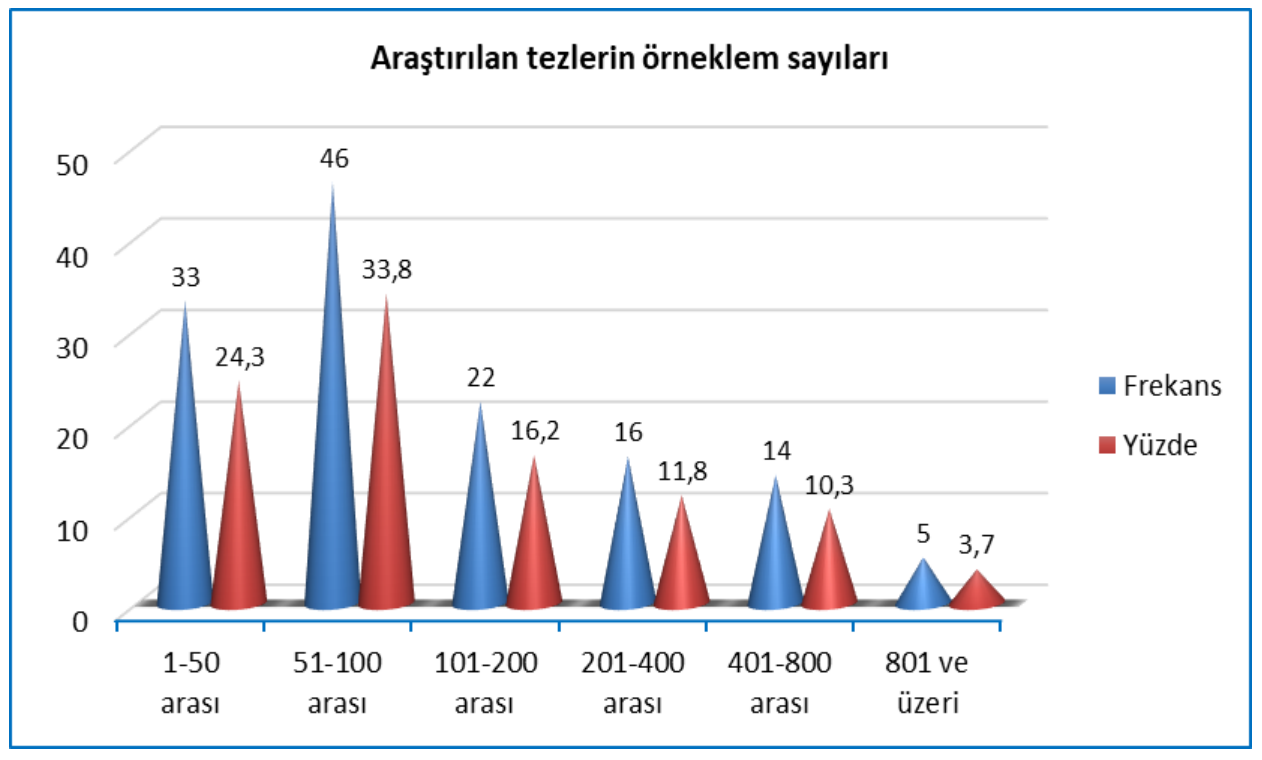

Şekil 9. Araştırılan tezlerin örneklem sayılarına göre frekans dağılımları 
Van YYÜ Eğitim Fakültesi Dergisi (YYU Journal of Education Faculty),2022:Şubat Özel Sayı 182-213,http://efdergi.yyu.edu.tr,

Şekil 9'a göre, araştırılan tezlerin çoğu 46 (\%33,8) tezle “51-100 arası” örneklem sayısına sahip örneklem gruplarıyla çalıştığı gözlenmiştir. Bunu takip eden diğer çalışmaların dağılımı ise sırasıyla şu şekildedir; 33 (\%24,3) tezle "1-50 arası", 22 (\%16,2) tezle "101-200 arası", $16(\% 11,8)$ tezle "201-400 arası", $14(\% 10,3)$ tezle "401-800 arası" ve $5(\% 3,7)$ tezle "801 ve üzeri” olan örneklem sayılarıdır.

\section{Araştırılan tezlerin "Veri toplama araçları" temaları}

Alt problemlerde belirtildiği gibi araştırılan tezlerin veri toplama araçları ve dağılımları incelenerek elde edilen bulgular Şekil 10'da gösterilmiştir.

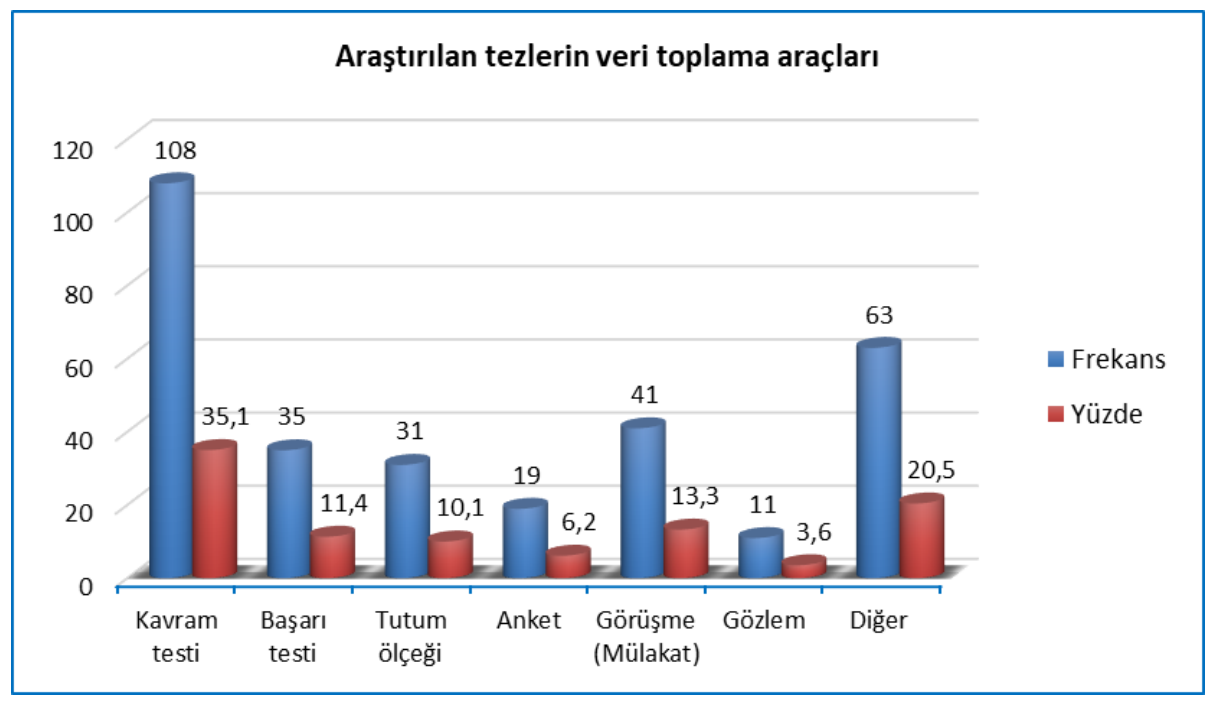

Şekil 10. Araştırılan tezlerin veri toplama araçlarına göre frekans dağılımları

Bazı tezlerde birden fazla veri toplama aracı kullanılmıştır.

Şekil 10’a göre, araştırılan tezlerin çoğunda veri toplama aracı olarak $108(\% 35,1)$ tezde "Kavram testi" kullanıldığg gözlenmiştir. Bunu takip eden diğer tezlerin dağılımı ise sırasıyla şu şekildedir; $35(\% 11,4)$ tezle "Başarı testi”, $31(\% 10,1)$ tezle "Tutum ölçeğii", 19 $(\% 6,2)$ tezle "Anket”, 41 (\%13,3) tezle "Görüşme (Mülakat)", $11(\% 3,6)$ tezle "Gözlem" ve $63(\% 20,5)$ tezle "Diğer" veri toplama araçlarından oluşmaktadır.

\section{Araştırılan tezlerin "Sonuçlar" temaları}

Alt problemlerde belirtildiği gibi araştırılan tezlerin ulaştıkları sonuçlar ve dağılımları incelenerek elde edilen bulgular Şekil 11'de gösterilmiştir. 


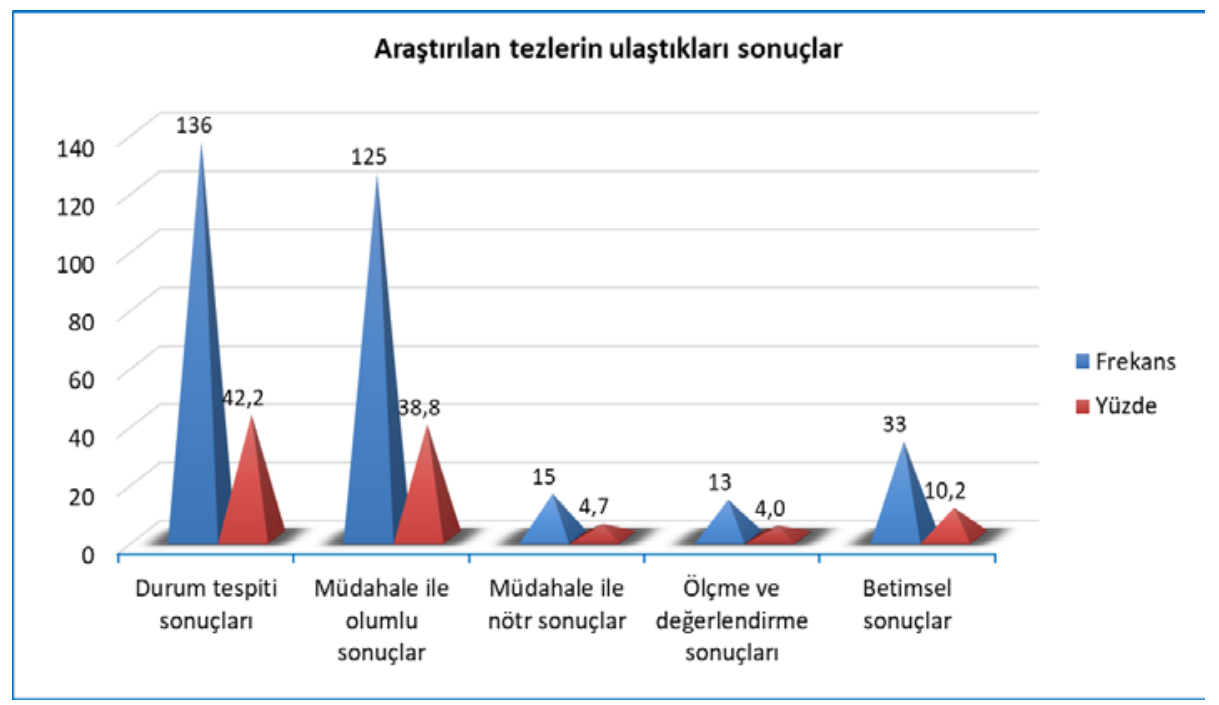

Şekil 11. Araştırılan tezlerin ulaştıkları sonuçlara göre frekans dağılımları

Bazı tezlerde birden fazla sonuca ulaşıldığı belirtilmiştir.

Şekil 11'e göre, araştırılan tezler ulaştıkları sonuçlar bakımından çoğunlukla iki grupta yığılma göstermişlerdir. Bunlar $136(\% 42,2)$ tezle "Durum tespitine yönelik sonuçlar” ve 125 $(\% 38,8)$ tezle "Müdahale edilerek alınan olumlu sonuçlar" şeklindedir. Bunları takip eden diğer çalışmaların ulaştıkları sonuçlar ise şu şekilde bir dağılım göstermektedir; $15(\% 4,7)$ tezle "Müdahale edilmesine rağmen sabit kalan (nötr) sonuçlar”, $13(\% 4,0)$ tezle “Ölçme ve değerlendirmeye ilişkin sonuçlar" ve 33 (\%10,2) tezle "Betimsel sonuçlar".

\section{Araştırılan tezlerin "Öneriler" temaları}

Alt problemlerde belirtildiği gibi araştırılan tezlerin sundukları öneriler ve dağılımları incelenerek elde edilen bulgular Şekil 11'de gösterilmiştir.

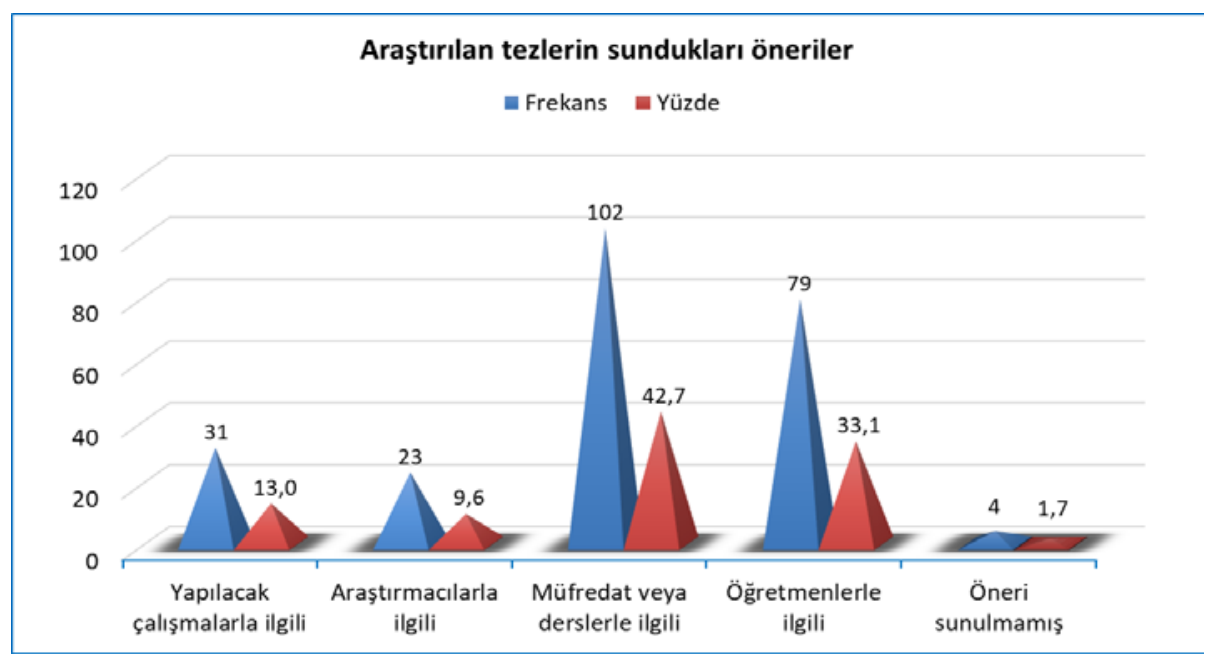

Şekil 12. Araştırılan tezlerin sundukları önerilere göre frekans dağılımları

Bazı tezlerde birden fazla öneri sunulduğu gözlenmiştir. 
Şekil 12'ye göre, sundukları öneriler bakımından araştırılan tezlerin yaklaşık olarak \%76'sı iki farklı grupta toplanmışlardır. Bunlar 102 (\%42,7) tezle "Müfredat veya derslerle ilgili öneriler” ve $79(\% 33,1)$ tezle “Öğretmenlerle ilgili öneriler” şeklindedir. Bunları takip eden diğer çalışmaların sundukları öneriler ise şu şekilde bir dağglım göstermektedir; 31 $(\% 13,0)$ tezde "Gelecekte yapılacak olan çalışmalarla ilgili öneriler", $23(\% 9,6)$ tezde “Araştırmacılarla ilgili öneriler” sunulurken, araştırma kapsamındaki toplam $4(\% 1,7)$ tezde herhangi bir öneriye rastlanmamıştır.

\section{Tartışma ve Öneriler}

Bu çalışmada, YÖK-Ulusal Tez Merkezi resmî Internet sitesindeki izinli tezlerden elde edilen verilere göre fen bilimleri eğitiminde karşılaşılan kavram yanılgılarıyla ilgili olarak 2001-2020 yılları arasında 20 doktora tezi ve 116 yüksek lisans tezi olmak üzere toplam 136 tane lisansüstü tez üzerinde araştırma yapılmıştır. Zaten 2001 yılından daha önce Ulusal Tez Merkezi kayıtlarında kavram yanılgılarıyla ilgili toplam üç tane tez bulunmakta ve bunların üçü de indirme izni olmayan yüksek lisans tezleridir. Dolayısıyla bu çalışma, izinli tezler kapsamında; fen bilimleri eğitiminde karşılaşılan kavram yanılgılarına ilişkin günümüze kadar yapılmış bütün lisansüstü tezleri kapsamaktadır.

Elde edilen bulgulara göre tezlerin türleri, konuları, yayın yılları, yazım dilleri, yayımlandığı enstitüler, amaçları, araştırma konuları, araştırma yöntemleri, veri analiz yöntemleri, örneklemleri (çalışma grupları), örneklem sayıları, veri toplama araçları, ulaşılan sonuçlar ve sunulan öneriler bakımından fen bilimleri eğitiminde kavram yanılgılarına ilişkin lisansüstü tezler tespit edilerek ayrı ayrı incelenmiştir.

İncelemeler sonucunda ilk göze çarpan şey fen bilimleri eğitiminde kavram yanılgılarına ilişkin lisansüstü tezlerin (Polat, 2013; Aydoğan ve Köksal, 2017; Yavuz, 2017; Batd1, 2019) yıllara göre dağılım farkıdır. Başka bir deyişle 2001-2020 yılları arasında ortalama yılda bir doktora tezi yapılırken, yüksek lisans tezlerinin yıllık ortalaması yaklaşık altıdır. Ayrıca doktora tezleri yıllara göre hemen hemen eşit bir şekilde dağılırken, yüksek lisans tezlerinde bir dalgalanma söz konusudur. 2005-2008 yılları arasında biraz hareketlenen yüksek lisans tezleri 2018-2019 yılları arasında pik yapmıştır. Bu tanıma uygun olarak bir yılda 13 tez hazırlanmıştır. Diğer yıllarda ise kavram yanılgılarıyla ilgili çalışmalarda durgunluk yaşandığ1 görülmektedir. 
Dikkat çeken diğer bir konu ise "araştırmanın amacı ve konusu" temalarına ait çalışılan doktora tezlerinin tamamının, yüksek lisans tezlerinin ise \%99'unun kavram yanılgılarını belirleme ve giderme (Riche, 2000; Nakiboğlu ve Özkılıç Arık, 2005; Uyanık ve Dindar, 2016; Ecevit ve Şimşek, 2017; Karaer, 2019) üzerine yoğunlaşmış olmasıdır. Zaten kavram yanılgılarını gidermeye yönelik araştırmalar açısından yerli literatür incelendiğinde fen bilimleri eğitiminin öne çıktığı görülmektedir (Çepni, 2009). Benzer durum "araştırma yöntemi” temalarında da görülmüş ve incelenen tezlerde çoğunlukla "deneysel” veya "yarı deneysel” yöntemler başta olmak üzere çoğunlukla nicel araştırma yöntemleri tercih edildiği gözlenmiştir.

Bütün tezlerde görüldüğü gibi "Veri analiz yöntemi” teması bakımından çoğunlukla “frekans-yüzde" ve "t testi” öne çıkmaktadır. Ayrıca kavram yanılgılarını gidermeye yönelik (Yakmacı-Güzel, 2014; Uyanık ve Dindar, 2016; Köğce, Yıldız ve Aydın, 2019) olarak tezleri hazırlayan kişiler tarafından değişik isimler altında geliştirilen testler üçüncü sırayı almaktadır. Söz konusu testlere bu çalışma da “Özel testler” adı verilmiştir.

Her iki tez türünde de eşit paydanın olduğu bir başka tema ise "Örneklem sayısı" temasıdır. Tezlerde çoğunlukla 51-100 arası kişinin araştırmaya katıldığı örneklem sayısı kullanılmıştır. Tezlerin "Örneklem (çalışma grubu)" temalarında, doktora tezlerinde lisans öğrencileri ile çalışmak tercih edilirken yüksek lisans tezlerinde ilköğretim (6-8) öğrencileri ile çalışmak öne çıkmaktadır. Genel olarak tezlerin veri toplama araçlarına bakıldığında, doktora tezlerinde çoğunlukla "kavram testi", "tutum ölçeği” ve "görüşme (mülakat)" tekniği (Laçin Şimşek, 2019) kullanırlarken, yüksek lisans tezlerinde ise genellikle "kavram testi" tercih edildiği görülmektedir.

"Sonuçlar" temaları bakımından tezlerin ulaştıkları sonuçlar incelendiği zaman, tezlerin çoğunlukla kavram yanılgılarına ilişkin "durum tespiti sonuçları" ve "müdahale ile olumlu sonuçlar” şeklindeki sonuçlara ulaştıkları tespit edilmiştir. Bu çalışmalarda genellikle yapılan müdahalelerin yerinde olduğu ve olumlu sonuçların alındığı bildirilmiştir (Uyanık ve Serin, 2016; Bağ ve Çalık, 2018). Dolayısıyla kavram yanılgılarını gidermeye yönelik çalışmaların uygulamalı olarak yürütülmesinin etkili bir yöntem olduğu vurgulanmıştır.

“Öneriler” temaları bakımından (Yakmacı-Güzel, 2016) tezlerin sundukları öneriler incelendiği zaman tezlerde ağırlıklı olarak "müfredat veya derslerle ilgili” ve "öğretmenlerle ilgili” sunulan önerilerin daha fazla olduğu belirlenmiştir. 
Fen bilimleri eğitiminde karşılaşılan kavram yanılgıları ile ilgili yapılan tezlerin ulaştıkları sonuçlara bakıldığı zaman, yüksek oranda "müdahale ile olumlu sonuçlar" alınması dikkat çekicidir. Bu durumda hem fen bilimleri dersi programındaki (MEB, 2018) kavram yanılgıları konulu çalışmalara devam edilmeli hem de fen bilimleri eğitimi dışındaki diğer alanlarla (Yılmaz, Türkoğuz ve Şahin, 2014; Köğce, Yıldız ve Aydın, 2019) ilgili de kavram yanılgıları konulu çalışmalar yapılmalıdır.

Araştırılan tezlerdeki örneklem grupları incelendiğinde, 26 tezde $(\% 17,4)$ "İlköğretim (4-5)" ve 55 tezde (\%36,9) “İlköğretim (6-8)” örneklem grupları ile çalışıldığ1 gözlenmektedir. $\mathrm{Bu}$ oranlar araştırma kapsamındaki bütün tezlerin yarısından fazladır ve aslında oldukça yüksektir. Ancak diğer örneklem gruplarına kıyasla yaşlarının küçük olduğu göz önünde bulundurulursa, bu yaşlardaki öğrencilerin fen bilimlerine ilişkin kavram yanılgılarına maruz kalmalarının normal karşılanması gerektiği düşünülmektedir. Çünkü "Sonuç" temaları bölümünde belirtildiği gibi kavram yanılgılarını gidermeye yönelik çalışmalardan "müdahale ile olumlu sonuçlar" alındığına göre öğrencilerdeki mevcut kavram yanılgılarının daha erken yaşlarda giderilmesi durumunda söz konusu alanla ilgili tutumların ve ileriye yönelik akademik başarıların da artması beklenmektedir.

Öğrencilerdeki hali hazırda var olan fen bilimleri ile ilgili kavram yanılgılarını belirlemek ve gidermek için gözlem, görsel eğitim, canlandırma, benzeşim vb. uygulama ağırlıklı yöntemler de kullanılabilir (White, 1994; Ülgen, 2001). Başka bir deyişle kavram yanılgılarına ilişkin çalışmalarda, sadece nicel araştırma yöntemleri kullanmak yerine tezlerin nitel araştırma yöntemleriyle desteklenmesi önerilmektedir.

Araştırmadaki alt problemlerde belirtilen temalara yönelik elde edilen bulguların ve sonuçların, başta fen bilimleri eğitimcileri olmak üzere, benzer çalışmalar yapan bütün araştırmacılara yardımcı olması ve yol göstermesi beklenmektedir. Hangi alanda araştırma yapılırsa yapılsın, akademik çalışmalarla uğraşan insanların günümüze kadar yapıllmış olan bütün çalışmaların amaç, yöntem, analiz, örneklem gibi araştırma künyelerini bilmeleri çok önemlidir. Çünkü söz konusu bilgilerin, bundan sonra yapılacak olan araştırmalara kılavuzluk etmeleri ve bilimsel gelişmelere katkı sağlamaları bakımından önemli rolleri bulunmaktadır. 


\title{
Makalenin Bilimdeki Konumu
}

\author{
Matematik ve Fen Bilimleri Eğitimi / Fen Bilgisi Eğitimi
}

\section{Makalenin Bilimdeki Özgünlüğü}

Fen bilimleri eğitiminde karşılaşılan kavram yanılgılarına ilişkin son yirmi yılda yapılan lisansüstü tezlerin tematik içerik analizinin yapılması, özellikle bu kadar geniş zaman aralığında çalışılması bu araştırmaya özgünlük ve önem kazandırmaktadır. Araştırmadaki tezlerin türleri, yayın yılları, yazım dilleri, yayımlandıkları enstitüler, amaçları, konuları, araştırma yöntemleri, veri analiz yöntemleri, çalışma grupları, örneklem sayıları, veri toplama araçları, ulaştıkları sonuçlar ve sundukları önerilerden oluşan tema zenginliği bakımından farklılık göstermektedir. Ayrıca daha önce hiç değinilmemiş olan alt problemlere sahip olması bakımından alan yazına ve bundan sonra yapılacak olan ilgili çalışmalara 1şık tutması beklenmektedir.

\section{Kaynaklar}

Adıgüzel, T., Şimşir, F., Çubukluöz, Ö., Gökkurt Özdemir, B. (2018). Master's Theses and Doctoral Dissertations on Misconceptions in Mathematics and Science Education in Turkey: A Thematic Analysis. Bayburt Eğitim Fakültesi Dergisi, 13(25), 57-92.

Aydoğan, Ş. ve Köksal, E. A. (2017). İlköğretim fen eğitiminde kavram yanılgıları konusunda yapılan çalışmaların içerik analizi. Eğitimde Kuram ve Uygulama, 13, 232-260.

Bacanak A., Küçük M. ve Çepni S. (2004). İlköğretim öğrencilerinin fotosentez ve solunum konularındaki kavram yanılgılarının belirlenmesi: Trabzon örneklemi. On Dokuz Mayıs Üniversitesi Ĕ̈itim Fakültesi Dergisi, 23, 67-80.

Bağ, H. ve Çalık, M. (2018). İlkokul 4. sınıf düzeyindeki fen eğitimi araştırmalarının tematik içerik analizi. Elementary Education Online, 17(3). 1353-1377.

Batd1, V. (2019). Meta-tematik analiz. Batd1, V. (Ed.), Meta-tematik analiz örnek uygulamalar içinde, (1-76). Ankara: Anı Yayıncılık.

Clement, J. (1993). Using bridging analogies and anchoring intuitions to deal with students' preconceptions in physics. Journal of Research in Science Teaching, 30, 1241-1257.

Çalık, M. ve Sözbilir, M. (2014). İçerik analizinin parametreleri. Eğitim ve Bilim Dergisi, 39(174), 33-38. 
Çepni, S. (2009). Effects of computer supported instructional material in removing students' misconceptions about concepts: Light, light source and seeing. Energy Education Science and Technology Part B: Social and Educational Studies, 1(2), 51-83.

Çepni, S. (2018). Araştırma ve proje çalışmalarına giriş (8. Baskı). Trabzon.

Çepni, S. ve Ayaş, A. P. (2005). Kuramdan uygulamaya fen ve teknoloji öğretimi. Pegem Akademi Yayıncılık.

Dinçer, S. (2018). Eğitim bilimleri araştırmalarında içerik analizi: Meta-analiz, meta-sentez, betimsel içerik analizi. Bartın Üniversitesi Eğitim Fakültesi Dergisi, 7(1), 176-190

Ecevit, T. ve Şimşek, P.Ö. (2017). Öğretmenlerin fen kavram öğretimleri, kavram yanılgılarını saptama ve giderme çalışmalarının değerlendirilmesi, Çevrimiçi Temel Eğitim, 16(161), 129-150. http://ilkogretim-online.org.tr/index.php/io/article/view/ 1120. Erişim tarihi: 5.01.2021.

Eryilmaz, A. (2002). Effects of conceptual assignments and conceptual change discussions on students' misconceptions and achievement regarding force and motion. Journal of Research in Science Teaching, 39(10), 1001-1015.

Kaptan, F. (1999). Fen bilgisi öğretimi. İstanbul: M. E. Basımevi.

Karaer, H. (2019). Determination of some misconceptions in solution concentrations of the teacher candidates and examination regarding to some variables of comprehension levels. Erciyes J. of Education, 3(2), 87-104. https://doi.org/10.32433/eje.558440

Koray, Ö., Özdemir, M. ve Tatar, N. (2005). İlköğretim öğrencilerinin “Birimler” hakkında sahip oldukları kavram yanılgıları: Kütle ve ağırlık örneği. Ilköğretim Online, 4(2), 24-31.

Köğce, D., Yıldız, C., \& Aydın, M. (2019). Matematik öğretmen adaylarının matematiksel kavram yanılgılarını belirlemeye, gidermeye ve kavram öğretimine ilişkin görüşlerinin incelenmesi. Cumhuriyet International Journal of Education, 8(2), 453-478.

Laçin Şimşek, C. (2019). Fen öğretiminde kavram yanılgıları tespiti ve giderilmesi. Pegem Akademi Yayıncılık.

MEB. (2018). Fen bilimleri dersi ögretim programı, ilkokul ve ortaokul 3, 4, 5, 6, 7 ve 8. Sınıflar. Talim ve Terbiye Kurulu Başkanlığı. MEB Yayınevi.

Nakiboğlu, C. ve Özkılıç Arık, R. (2005). 4. Sınıf öğrencilerinin "gazlar” ile ilgili kavram yanılgılarının V-diyagramı kullanılarak belirlenmesi. Yeditepe Üniversitesi Ĕ̈itim Fakültesi Dergisi, 1-17. 
Van YYÜ Eğitim Fakültesi Dergisi (YYU Journal of Education Faculty),2022:Şubat Özel Sayı 182-213,http://efdergi.yyu.edu.tr,

Özkan, U. B. (2019). Ĕ̆itim bilimleri araştırmaları için doküman inceleme yöntemi. (1.Bask1). Ankara: Pegem Akademi Yayıncılık.

Polat, M. (2013). Fen bilimleri eğitimi alanında tamamlanmış yüksek lisans tezleri üzerine bir araştırma: Celal Bayar üniversitesi örneği. Buca Eğitim Fakültesi Dergisi, 35, 46-58.

Polat, S. ve Ay, O. (2016). Meta-sentez: kavramsal bir çözümleme. Eğitimde Nitel Araştırmalar Dergisi, 4(1),52-64.

Riche, R. D. (2000). Strategies for Assisting Students Overcome Their Misconceptions in High School Physics. Memorial University of Newfoundland Education, 6390.

Senemoğlu, N. (2004). Gelişim, öğrenme ve öğretim: kuramdan uygulamaya. 9. Bask1. Gazi Kitabevi.

Sinan, O. (2010). Öğretmen adaylarının kimya ve biyoloji derslerinde kullanılan bazı ortak kavramları tanımlamalarındaki farklılıklar-II. Necatibey Eğitim Fakültesi Elektronik Fen ve Matematik Eğitimi Dergisi, 4(1), 85-107.

Tayan, E, Gedik, S., Morkoyunlu, Z., Sözbilir, M., Konyalığlu, A. (2019). Ebeveyn-çocuk ilişkisi konulu makaleler: Tematik içerik analizi çalışması. Eskişehir Osmangazi Üniversitesi Sosyal Bilimler Dergisi, Armă̆an Özel Sayısı, 20, 1183-1208.

TDK Sözlük. (2021). Erişim tarihi: 5.01.2021. https://sozluk.gov.tr/?kelime=KAVRAM.

Türkdoğan, A., Güler, M., Bülbül, B., Danişman, Ş. (2015). Türkiye’de matematik eğitiminde kavram yanılgılarıyla ilgili çalışmalar: Tematik bir inceleme. Mersin Üniversitesi Eğitim Fakültesi Dergisi, 11(2). https://doi.org/10.17860/efd.26545.

Uyanık, G., Dindar, H., (2016). İlkokul 4. Sınıf Fen Bilimleri Dersinde Kavramsal Değişim Metinlerinin Kavram Yanılgılarının Giderilmesine Etkisi. Gazi Eğitim Fakültesi Dergisi, 36(2), 349- 374.

Uyanık, G. ve Serin, M. K. (2016). Sınıf öğretmeni adaylarının bazı temel fen konularındaki kavram yanılgılarının belirlenmesi. Amasya Üniversitesi Eğitim Fakültesi Dergisi, 5(2), 510-538.

Ülgen, G. (2001). Kavram Geliştirme. Ankara: Pegem Akademi Yayıncılık.

White, R. T. (1994). Commentary: Conceptual and conceptual change. Learning and Instruction, 4(1), 117-121.

Yağbasan, R. ve Gülçiçek, Ç. (2003). Fen öğretiminde kavram yanılgılarının karakteristiklerinin tanımlanması. Pamukkale Üniversitesi Eğitim Fakültesi Dergisi, 13(13), 102-120. 
Van YYÜ Eğitim Fakültesi Dergisi (YYU Journal of Education Faculty),2022:Şubat Özel Sayı 182-213,http://efdergi.yyu.edu.tr,

Yakmacı-Güzel, B. (2016). 12. sınıf öğrencilerinin bazı temalardaki kimya kavram yanılgılarının belirlenmesi ve bu bulguların etkili kullanımına dair öneriler. Boğaziçi Üniversitesi Ĕ̈itim Dergisi, 31 (2), 5-26.

Yakmacı-Güzel, B. (2014). 12. Sınıf öğrencilerinin bazı temalardaki kavram yanılgılarının belirlenmesi ve bu bulguların etkili kullanımına dair öneriler. Boğaziçi Üniversitesi Eğitim Fakültesi Dergisi, 31(2), 5-26.

Yanarateş, E. (2021). Fen bilimleri öğretimi ve teknoloji kullanımında güncel yaklaşımlar. Talan, T. (Ed.), Eğitimde Dijitalleşme ve Yeni Yaklaşımlar içinde (s.59-104). Efe Akademi.

Yanarateş, E. ve Yılmaz, A. (2020). Öğretmen adaylarının “çevre duyarlılı̆̆ı” kavramına yönelik metaforik algıları. Gazi Üniversitesi Gazi Ĕ̈itim Fakültesi Dergisi, 40(3), 1019-1050. https://doi.org/10.17152/gefad. 699406

Yavuz, S. (2017). Kimya eğitimi alanında kavram yanılgıları ile ilgili tamamlanmış tezler üzerine bir içerik analizi: Türkiye örneği (2005-2015). Kastamonu Eğitim Dergisi, 25(3), 957-974

Yıldırım, A. ve Şimşek, H. (2018). Sosyal bilimlerde nitel araştırma yöntemleri, (11. Baskı). Seçkin Yayıncılık.

Yılmaz, A. ve Bayrakçeken, S. (2017). Öğretmen adaylarının elektrokimya konusundaki kavram yanılgılarının belirlenmesi. Bayburt Eğitim Fakültesi Dergisi, 12(24), 881896.

Y1lmaz, A. ve Yanarateş, E. (2020). Determination of metaphorical perceptions of prospective teachers on the concept of "water pollution" through triangulation. Kastamonu Education Journal, 28(3), 1500-1528. https://doi.org/10.24106/kefdergi.722554.

Yılmaz, E., Türkoğuz, S. ve Şahin, (2014). Güneş sistemi ve uzay konularına yönelik kavram yanılgılarının günlük yaşama etkisi üzerine öğretmen görüşleri, Buca Eğitim Fakültesi Dergisi, 37, 37-44.

YÖK. (2021). Ulusal Tez Merkezi (5.01.2021). https://tez.yok.gov.tr/UlusalTezMerkezi.

YÖK/Dünya Bankas1. (1997). Millî eğitimi geliştirme projesi hizmet öncesi öğretmen ĕgitimi. 


\section{Extended Summary}

\section{Thematic Content Analysis of Graduate Theses on Misconceptions Encountered in}

\section{Science Education in Turkey}

\section{Problem Statement}

In everyday life, students gain various experiences within the scope of science education. Sometimes these experiences allow them to access the correct information, and sometimes they can cause them to get false information. These experiences create the knowledge of the students. The learning phenomenon is based on understanding such information by establishing a relationship between the pre-existing information and the information learned later. It is crucial to identify the false concepts in the student's knowledge vocabulary because the wrong concepts learned in everyday life can prevent students from learning (Yağbasan and Gülçiçek, 2003).

The descriptive content analysis method should be preferred in studies that examine qualitative and quantitative research on the topic researched (Polat \& Ay, 2016). To show the general situation in the research where this method is used, no detailed interpretation is made by specifying the general pattern of any theme with frequency and percentage data only (Dinçer, 2018). In this context, if quantitative and qualitative studies are to be discussed together and a general situation is revealed, the descriptive content analysis should be used. In this context, this study is a thematic content analysis to determine the general trends of masters and doctoral theses on the misconceptions encountered in science education in Turkey. Similar themes also show previous research on these theses. The increasing number of academic studies on misconceptions shows the importance of this topic and the need for some solutions. The rate of study of the theses in this research has also been higher in recent years.

In light of these expectations, the study's purpose is; a comprehensive examination of the thematic content analysis of graduate theses on the misconceptions encountered in science education in Turkey. For this purpose, all the theses allowed in the official website records of the CoEH-National Thesis Center and whose names the keywords "science" and "misconceptions" are mentioned together are used. Therefore, the sample of the study consists of 136 authorized theses made between 2001 and 2020 . 


\section{Purpose of the Study}

In this study, what is the classification of master's and doctoral theses on the misconceptions encountered in science education in Turkey between 2001 and 2020, the issues of the publication, writing languages, published institutes, objectives, research subjects, research methods, data analysis methods, sampling methods, sampling numbers, data collection tools, results and recommendations? For this purpose, answers to the following questions have been sought.

Regarding the misconceptions encountered in science education;

1. How does the number of theses vary by year?

2. How do theses vary according to the writing languages?

3. What is the distribution of the institutes where the theses are published?

4. What are the purposes of the theses in general?

5. What topics are investigated in the theses?

6. What research methods were used in the theses?

7. What data analysis methods were used in the theses?

8. What are the samplings (working groups) of the theses?

9. How do the sample sizes of the theses change?

10. What data collection tools were used in the theses?

11. What kind of results were found in the theses?

12. What suggestions are presented in the theses?

\section{Method}

In this research, which was carried out using the screening model from descriptive research methods, the descriptive content analysis method was used, which discussed the studies related to misconceptions within Turkey's science education scope. This method is synthesis and interpretation activities made by determining quantitative and qualitative research themes and examining similar subjects (Calik and Sözbilir, 2014). Some misconceptions may arise about content analysis. These misconceptions are probably that the concept of content analysis is sometimes referred to as "research method" and sometimes as "data analysis method". Therefore, these misconceptions can often cause contradictions that tend to classify research as quantitative-qualitative. Descriptive content analysis is a method that shows the general situation and provides general information on the subject using the 
frequencies and percentages of specific themes. This method does not include detailed interpretations (Dinçer, 2018). The basic principle in the thematic content analysis, which emphasizes the function of a depiction of science, is to classify and understandably edit and interpret the data obtained by scanning the literature within the previously determined concept and theme (Lightning and Lightning, 2018).

On the other hand, content/document analysis a research method that focuses on quantitative and qualitative studies. The descriptive content analysis mainly aims to provide information on the general outlines of the research. In contrast, the thematic content analysis provides more detailed information because the number of studies focused is less (Çepni, 2018). In this study, thematic content analysis was approved. It aimed to examine the studies related to the misconceptions made within the scope of science education in Turkey and identify the themes.

\section{Findings and Discussion}

The theses in the research sample were examined in line with the identified subproblems. The findings obtained by classifying the data collected from the review as thematic are presented in twelve sections the following thematic.

1. The "publication years" themes of the researched theses

2. The "Writing languages" themes of the researched theses

3. The "Institutes where they have published" themes of the researched theses

4. The "Purpose of the study" themes of the researched theses

5. The "Research topic" themes of the researched theses

6. The "Research methods" themes of the researched theses

7. The "Data analysis" themes of the researched theses

8. The "Population and sample" themes of the researched theses

9. The "Sample size" themes of the researched theses

10. The "Data collection tools" themes of the researched theses

11. The "Results or Conclusions" themes of the researched theses

12. The "Recommendations" themes of the researched theses 


\section{Conclusion and Recommendations}

When we look at the results of the theses on the misconceptions encountered in science education, it is noteworthy that a high rate of "positive results with intervention" is obtained. In this case, both studies on misconceptions in science education should be continued, and studies on misconceptions should be carried out in fields other than science education.

The findings and results of the themes mentioned in the research sub-problems are expected to help and guide all researchers who have done similar studies, especially science educators. Regardless of which field of research is carried out, it is crucial for people engaged in academic studies to know the research tags such as purpose, method, analysis and sampling of all the studies that have been done to date because this information has a crucial role to play in guiding future research and contributing to scientific developments.

Application-oriented methods such as observation, visual education, animation, affinity, etc., can also be used to identify and eliminate existing cognitive misconceptions in students. In other words, in studies on misconceptions, it is recommended to support theses with qualitative research methods instead of just quantitative research methods.

Keywords: Science education, concept, misconceptions, thematic content analysis.

\section{Etik Kurul Kararı}

Kastamonu Üniversitesi Sosyal ve Beşerî Bilimler Araştırma ve Yayın Etik Kurulu 25/03/2021 tarih ve 29 sayılı kararı: Araştırma makalesinde dosya taraması, veri kaynakları taraması ve dokuman incelemesi yapılacağı belirtildiğinden ötürü Etik Kurul iznine ihtiyaç olmadığına toplantıya katılan üyelerin oy birliği ile karar verilmiştir. 
Ekler

Ek 1. Araştırma kapsamında incelenen doktora tezleri (YÖK, 2021)

\begin{tabular}{|c|c|c|c|}
\hline Kod & Tez no & Tez adi (Doktora) & Yil \\
\hline \multicolumn{4}{|c|}{ Ĕgitim Bilimleri Enstitüsü } \\
\hline D1 & 286527 & “Öğrencilerin ‘Hücre Bölünmesi ve Kalıtım’ konularındaki ka & 2011 \\
\hline D2 & 298432 & "Sorgulayıcı araştırmaya dayalı laboratuvar ile doğrulayıcı labo & 2011 \\
\hline D3 & 299731 & "5E modeline dayalı olarak hazırlanan ders yazılımının öğrencilerin ..." & 2011 \\
\hline D4 & 333541 & "Atom ve molekül konusunda kavram yanılgıları ve bunları ..." & 2013 \\
\hline D5 & 372248 & in 7. sinıf öğrencileri...” & 2014 \\
\hline D6 & 412429 & "Sınıf öğretmenliği öğretmen adaylarının kuvvet ve hareket konusu..." & 2015 \\
\hline D7 & 442976 & "5. sınıf 'yaşamımızın vazgeçilmezi: Elektrik' ünitesinde kullanılan ...”" & 2016 \\
\hline D8 & 472006 & "Fen bilgisi öğretmen adaylar & 2017 \\
\hline D9 & 529997 & "Art11 & 2018 \\
\hline D10 & 624160 & "Ortaokul 7. sinıf öğrencilerinin kuvvet ve hareket konusunda sahip ..." & 2020 \\
\hline \multicolumn{4}{|c|}{ Fen Bilimleri Enstitüsü } \\
\hline D11 & 156154 & "Fen bilgisi öğretmen adaylarında fotosentez ve bitkilerde solunum ..." & 2004 \\
\hline D12 & & "Fen & \\
\hline D13 & 199364 & acak temel ..." & 2007 \\
\hline D14 & 212034 & "Aktif katılımlı materyal geliştirme sürecinin biyoloji öğretmen ..." & 2007 \\
\hline D15 & 213909 & "Öğretmen adaylarının Newton'un hareket kanunları konusundaki ...” & 2008 \\
\hline D16 & 245494 & "İnsanda sindirim sistemi kon & 2009 \\
\hline D17 & 269347 & n geometrik ...” & 2010 \\
\hline D18 & 305019 & "Kavramsal değişim metni yaklaşımına dayalı öğretim ve öğrencilerin ..." & 2012 \\
\hline D19 & 318966 & "Fizik öğretmen adaylarının geometrik optik ile ilgili kavram ..." & 2012 \\
\hline D20 & 337073 & "Fen bilgisi öğretmen adaylarının radyoaktivite konusundaki kavram ..." & 2013 \\
\hline
\end{tabular}

Ek 2. Araştırma kapsamında incelenen yüksek lisans tezleri (YÖK, 2021)

\begin{tabular}{|c|c|c|c|}
\hline Kod & Tez no & Tez adı (Yüksek Lisans) & Yll \\
\hline & & Ĕgitim Bilimleri Enstitüsü & \\
\hline YL1 & 133724 & "İlköğretim 6. sınıf öğrencilerinin dünya ve evren konusu ile ilgili ...” & 2003 \\
\hline YL2 & 133943 & "Sınıf öğretmeni adaylarının ısı ve sıcaklık konusundaki kavram ..." & 2003 \\
\hline YL3 & 140117 & "Fen bilgisi öğretmen adaylarının piller ve elektroliz hücreleri ..." & 2003 \\
\hline YL4 & 145192 & "İlköğretim 8. sınıf ve ortaöğretim 11. sınıf öğrencilerinin alan ve ..." & 2004 \\
\hline YL5 & 145233 & "Buharlaşma, kaynama konularındaki kavram yanılgılarının önlenmesi ...” & 2004 \\
\hline YL6 & 159234 & "İlköğretimde basınç konusunda öğrencilerin sahip olduğu kavram ...” & 2005 \\
\hline YL7 & 188711 & "Fen bilgisi öğretiminde oluşan kavram yanılgılarının proje tabanlı ..." & 2005 \\
\hline YL8 & 188718 & “İlköğretim öğrencilerinin sahip oldukları kavram yanılgılarının ...” & 2005 \\
\hline YL9 & 189810 & "Ausubel'in sunuş yöntemi ile, bilgisayar destekli öğretim ...” & 2006 \\
\hline YL10 & 191735 & "Fen öğretiminde aktif öğrenmenin kavram yanılgılarını gidermeye etkisi" & 2006 \\
\hline YL11 & 207017 & "İlköğretim öğrencilerinin (6.,7. ve 8. sınıflar), hücre konusundaki ..." & 2006 \\
\hline YL12 & 206996 & “Sınıf öğretmenliği öğretmen adaylarının kuvvet, hareket ve ses ...” & 2007 \\
\hline YL13 & 207156 & "Kuvvet ve hareket konusu ile ilgili öğrencilerin kavram yanılgılarının ..." & 2007 \\
\hline YL14 & 210293 & "Maddedeki değişim ve enerji ünitesindeki kavram yanılgılarının tespiti..." & 2007 \\
\hline YL15 & 211465 & "İlköğretim düzeyinde 5. sınıf fen ve teknoloji dersi canlılar ve hayat ..." & 2007 \\
\hline YL16 & 230948 & "Fen ve teknoloji dersinde proje tabanlı öğrenme yöntemi kullanımının ..." & 2008 \\
\hline YL17 & 264328 & "Probleme dayalı öğrenme yönteminin ilköğretim 5. sınıf öğrencilerinin..." & 2010 \\
\hline YL18 & 356790 & "Fen bilgisi öğretmen adaylarının kimyasal bağlar konusundaki kavram..." & 2013 \\
\hline YL19 & 357113 & "6.sınıf öğrencilerinde dolaşım sistemi konusunda görülen kavram ..." & 2013 \\
\hline YL20 & 357729 & "Fen bilimleri öğretmen adaylarının maddenin tanecikli yapısı konusu ..." & 2013 \\
\hline YL21 & 358141 & "İlköğretim beşinci ve yedinci sınıf öğrencilerinin astronomi ..." & 2013 \\
\hline YL22 & 358211 & "Aletli analiz yöntemi ile fen bilgisi öğretmen adaylarına adsorpsiyon ..." & 2013 \\
\hline YL23 & 401412 & "İlkokul ve ortaokul öğretmenlerinin beyin hakkındaki bilgileri ve ..." & 2013 \\
\hline
\end{tabular}




\begin{tabular}{|c|c|c|c|}
\hline 24 & 363165 & & 2014 \\
\hline Kod & Tez no & Tez adı (Yüksek Lisans) & Yil \\
\hline YL25 & 378513 & "Kavram karikatürlerinin ilköğretim yedinci sınıf öğrencilerinin basit ...” & 2014 \\
\hline YL26 & 395311 & "Sanal laboratuvar uygulamalarının $8 . \sin ı$ ö ögrencilerinin 'Maddenin ..." & 2015 \\
\hline YL27 & 395389 & "Biyoloji eğitiminde kavram yanılgıları: İgili araștırmaların incelemesi" & 2015 \\
\hline YL28 & 407724 & "Model ve etkinliklerle desteklenen öğretim sürecinin sindirim sistemi ..." & 2015 \\
\hline YL29 & 446346 & "EBA destekli öğretimin 4. sınıf öğrencilerinin ‘'sı-sıcaklık’ ve ...” & 2016 \\
\hline YL30 & 450118 & "İlköğretim 7. ve 8. sınıf öğrencilerinin sindirim ve beslenme ..." & 2016 \\
\hline YL31 & 450246 & "İşbirlikli öğrenme yönteminin 5. sınıf öğrencilerinin fen bilimleri ..." & 2016 \\
\hline lL32 & 471812 & "Fen bilgisi öğretmen adaylarının yoğunluk konusundaki kavram ..." & 2017 \\
\hline YL33 & 477320 & "6. sınıf öğrencilerinin ışık ve ses konusundaki kavram yanılgılarının ..." & 2017 \\
\hline YL34 & 477322 & "7.sınıf sindirim sistemi konusunda iki aşamalı test geliştirilerek ..." & 2017 \\
\hline YL35 & 481298 & "Fen bilgisi öğretmen adaylarının sıvı basıncı konusundaki kavram ..." & 2017 \\
\hline lL36 & 490560 & "5. sınıf ortaokul öğrencilerinin hava, su ve toprak kirliliği ile ilgili ..." & 2018 \\
\hline YL37 & 492311 & "Lise 3. sinıf öğrencilerinin kuvvet ve hareket konusundaki kavram ..." & 2018 \\
\hline YL38 & 498193 & "Fen bilgisi öğretmen adaylarında DNA replikasyonu ve protein ..." & 2018 \\
\hline YL39 & 505349 & "Türk öğrencilerin fen konularındaki yaygın kavram yanılgıları üzerine ..." & 2018 \\
\hline YL40 & 512216 & "Fen bilgisi öğretmeni adaylarının kuvvet ve hareket konularındaki ..." & 2018 \\
\hline YL41 & 514772 & "İlkokul 4. sınıf öğrencilerinin yön konusundaki kavram yanılgıları ..." & 2018 \\
\hline YL42 & 515020 & "4. sınıf fen bilimleri dersinde kavramsal değişim metinlerinin ..." & 2018 \\
\hline YL43 & 516676 & yoloji öğretmen adaylarının arkebakteri, bakteri ve protista ...” & 2018 \\
\hline YL44 & 527763 & "Dördüncü sınıf öğrencilerinin kavram yanılgılarının giderilmesine ve ..." & 2018 \\
\hline YL45 & 560590 & "Fen bilgisi öğretmen adaylarının gaz kanunları ile ilgili kavram ..." & 2019 \\
\hline YL46 & 561781 & "7. sınıf öğrencilerinin atom kavramı hakkındaki kavram yanılgıları" & 2019 \\
\hline YL47 & 571675 & ul öğrencilerinin 1sı ve sıcaklık konusundaki kavram yanılgıları ...” & 2019 \\
\hline YL48 & 574142 & "İlköğretim 7. sınıf öğrencilerinin bitkilerde üreme büyüme gelişme ...” & 2019 \\
\hline YL49 & 586109 & "Fen bilgisi öğretmen adaylarının gaz basıncı konusundaki kavram ..." & 2019 \\
\hline YL50 & 590016 & 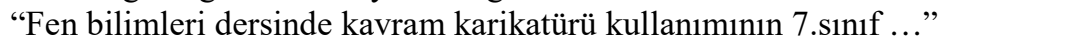 & 2019 \\
\hline YL51 & 602145 & "7. sınıf öğrencilerinin boşaltım konusundaki kavram yanılgılarının ..." & 2019 \\
\hline YL52 & 606144 & "Ortaokul 7. sınıf öğrencilerinin fen bilimleri dersi kapsamında ...” & 2019 \\
\hline YL53 & 609171 & "Ortaokul öğrencilerinin temel astronomi alanındaki konularla ..." & 2019 \\
\hline YL54 & 616350 & "Kavram ağlarıyla desteklenmiş TGA etkinliklerinin fen bilgisi & 2020 \\
\hline YL55 & 642971 & "Lise öğrencilerinin sürtünme kuvvetinin yönü konusundaki ..." & 2020 \\
\hline YL56 & 646316 & " 6,7 ve 8 . sinıf fen bilgisi öğrencilerin sindirim sisteminde yer ..." & 2020 \\
\hline
\end{tabular}

\section{Fen Bilimleri Enstitüsü}

YL57

YL58

YL59

YL60

YL61

YL62

YL63

YL64

YL65

YL66

YL67

YL68

YL69

YL70

YL71

YL72

YL73

YL74

YL75

YL76

YL77
116259

166885

169058

197195

197325

197592

180258

182933

182943

199350

177865

200942

200943

213461

213616

232372

232374

232377

233760

233773

237676

"Birleştirici benzetme ve örnekleme yönteminin lise öğrencilerinin ..."

"Dokuzuncu sınıf öğrencilerinin basit elektrik devreleri ile ilgili ..."

"İlköğretim ikinci kademe yedinci sınıf öğrencilerinin katı ve sıvıların ..."

"Lise öğrencilerinin elektrik akımı konusundaki kavram yanılgılarının ..."

"Ortaöğretimde 1s1, sıcaklık, genleşme ve elektrik akımı konularının ..."

"1992-2004 yilları arasında normal liselerde okutulan kimya-1 ders ..."

"Mitoz ve mayoz hücre bölünmesi konusundaki kavram ..."

"Fen ve teknoloji öğretiminde drama yönteminin kavram yantlglarının ..."

“İlköğretim 5. sınıf öğrencilerinde ‘yașamımızdaki elektrik' ünitesinde ...” 2006

"Kavramsal değişim yöntemi ile yapılan öğretimin onuncu sınıf ..." 2006

"Üç aşamalı soru tipi geliştirilerek ilköğretim 5. sınıf öğrencilerinin ..." 2007

"Hidrokarbon (alkan, alken ve alkin) konuları ile ilgili kavram ..." 2007

"Is1 ve sıcaklık konusunda rastlanan kavram yanılgıları ve bu kavram ..." 2007

“1995- 2006 yılları arasında liselerin II. sinıflarında okutulan kimya ...” 2007

"Fen ve matematik öğretmen adaylarının vektör uzayları teorisinde ..." 2008

"İlköğretim 6. sınıf öğrencilerinin kuvvet ve hareket konusunu anlama...” 2008

"Kavram yanılgılarının belirlenmesinde kavram karikatürlerinin ..." 2008

"İlköğretim sekizinci sınıf fen bilgisi (fen ve teknoloji) dersi genetik ...” 2008

"Kimyasal bağlar konusu ile ilgili kavram yanılgılarının belirlenmesi ...” 2008

“1995-2006 yılları arasında ilköğretim 7. sınıflarında okutulan fen ..." 2008

"Kavram yanılgısı ve çoklu zekâ alanlarının ilişkilendirilmesine dayalı ..." 2008 
Van YYÜ Eğitim Fakültesi Dergisi (YYU Journal of Education Faculty),2022:Şubat Özel Sayn 182-213,http://efdergi.yyu.edu.tr,

YL78 237730 "Üniversite öğrencilerinin çözeltiler konusundaki kavram yanılgıları" 2008

YL79 238034 "İlköğretim 8. sınıf öğrencilerinin sıvıların kaldırma kuvveti ile ilgili ...” 2009

\begin{tabular}{|c|c|c|c|}
\hline Kod & Tez no & Tez adı (Yüksek Lisans) & Yll \\
\hline YL80 & 246900 & "Doğru akım devreleri ile ilgili olarak 11. sınıf öğrencilerinde oluşmuş ..." & 2009 \\
\hline YL81 & 270040 & "Sınıf öğretmeni adaylarının gazlar konusundaki kavramlar ile ilgili ..." & 2010 \\
\hline YL82 & 270678 & "Senaryo tabanlı öğrenme yönteminin genetik konusundaki kavram ...”" & 2010 \\
\hline YL83 & 274851 & "6.sinıf öğrencilerinin kuvvet ve hareket konusundaki kavram yanılg1..." & 2010 \\
\hline YL84 & 274873 & "Çevre sorunları ile ilgili bazı kavram yanılgılarının yapılandırılmış ..." & 2010 \\
\hline YL85 & 275305 & "Fen bilgisi öğretmen adaylarında fotosentez ve bitkilerde solunum ..." & 2010 \\
\hline YL86 & 282923 & "İlköğretim 7. sınıf öğrencilerinin elektrostatik konusuyla ilgili kavram...” & 2011 \\
\hline YL87 & 325518 & "Aday kimya öğretmenlerinin alan bilgilerini, kavram yanılgılarına ..." & 2012 \\
\hline YL88 & 418052 & "8. sınıf kuvvet ve hareket ünitesindeki kavram yanılgılarının çalışma ..." & 2015 \\
\hline YL89 & 418437 & "Kavram yanılgılarının giderilmesinde simülasyonların etkisinin ..." & 2015 \\
\hline YL90 & 482277 & "6. sınıf öğrencilerinin maddenin & 2017 \\
\hline YL91 & 513708 & "Fen bilgisi ve sınıf öğretmeni adaylarının maddenin halleri ve 1s1..." & 2018 \\
\hline YL92 & 514302 & "Ortaokul 5 ve 8 . sinıf öğrencilerinin 1sı ve sicaklık konusundaki & 2018 \\
\hline YL93 & 531002 & "Ortac & 2018 \\
\hline YL94 & 559219 & "Ortaokul öğrencilerinin kimyasal bağlar konusunda sahip oldukları ...”" & 2018 \\
\hline YL95 & 569708 & "Onuncu sınıf öğrencilerinin çözeltiler konusuna yönelik kavram ..." & 2019 \\
\hline YL96 & 569596 & "Orta & 2019 \\
\hline YL97 & 591139 & demik ...” & 2019 \\
\hline YL98 & 593542 & "Kavram yanılgılarını gidermeye yönelik bilimsel tartışma odaklı ..." & 2019 \\
\hline YL99 & 633711 & bölünmesi ve kalıtım ...” & 2020 \\
\hline \multirow[t]{2}{*}{ YL100 } & 642527 & "Basit makineler ünitesinin öğretiminde kullanılan kavram ..." & 2020 \\
\hline & & Sosyal Bilimler Enstitüsü & \\
\hline 101 & 9594 & "Üni & 2006 \\
\hline YL102 & 189617 & "Farklı laboratuvar yaklaşımlarının ilköğretim 8. sınıf öğrencilerinin ...”" & 2006 \\
\hline YL103 & 208268 & "İlköğretim 5. sinıf fen ve teknoloji dersinde probleme dayalı öğrenme ..." & 2007 \\
\hline YL104 & 226954 & en bilgisi dersi kimya ..." & 2008 \\
\hline YL105 & 227623 & in eşitlikler konusundaki kavram ...” & 2008 \\
\hline YL106 & 228828 & "İlköğretim 5. sınıf fen ve teknoloji dersi, maddenin değişimi ve ..." & 2008 \\
\hline YL107 & 234852 & amsal değişim metinlerinin ve ...” & 2009 \\
\hline YL108 & 249629 & 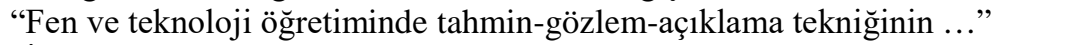 & 2010 \\
\hline YL109 & 258069 & "İlköğretim beşinci sınıf öğrencilerinin çevre, alan ve hacim konularına ..." & 2010 \\
\hline YL110 & 278552 & "Öğretmen adaylarının bilime yönelik kavram yanılgılarının ..." & 2010 \\
\hline YL111 & 278832 & "Öğrencilerin bilimsel düşünme evreleri ile hareket kuvveti gerek & 2011 \\
\hline YL112 & 300326 & n ayın evreleri konusunda kavram...” & 2011 \\
\hline YL113 & 308425 & "İlköğretim 8. sinıf fen ve teknoloji dersi 'maddenin halleri ve 1s1' ..." & 2011 \\
\hline YL114 & 345319 & "Sınıf öğretmenliği öğrencilerinin gazlar konusundaki kavram ..." & 2013 \\
\hline YL115 & 429873 & 2. - l. & 2016 \\
\hline YL116 & 470456 & "Sınıf öğretmeni adaylarının 1sı & 2017 \\
\hline
\end{tabular}

